\title{
The Rise and Fall of the Fraternal Life Insurer: Law and Finance in U.S. Life Insurance, 1870-1920
}

\author{
by \\ George Zanjani* \\ Federal Reserve Bank of New York \\ 33 Liberty Street \\ New York, New York 10045 \\ Phone: 212-720-6320 \\ Email: George.Zanjani@ny.frb.org
}

This Version: October, 2003

\begin{abstract}
This paper studies the rise and fall of fraternal life insurance in the decades surrounding 1900. It shows that the rise of the fraternal life insurer took place while it was exempt from the solvency regulations that governed other insurance companies, and its fade into obscurity followed soon after this exemption ended. Enactment of fraternal regulation at the state level was associated with large drops in fraternal insurer formations. The evidence challenges the notion that claimant protection laws "enabled" insurance organizations to succeed by enhancing public confidence in their operations, suggesting instead that they were a burden on industry.
\end{abstract}

*I thank Gary Becker, Pierre-Andre Chiappori, Darius Lakdawalla, Hamid Mehran, Tomas Philipson, and seminar participants at the University of Chicago and the Federal Reserve Bank of New York for helpful comments and discussions. Errors are mine. The views expressed in this article are those of the author and do not necessarily reflect the position of the Federal Reserve Bank of New York or the Federal Reserve System. 


\section{Introduction}

Recent research in finance has tended toward an enabling view of the law, especially law that protects the rights of parties to the corporation. Research built on the metrics of La Porta et al. [26], [27] (who connect strong investor protection laws with dispersion of corporate ownership) has found that investor protections promote efficiency and growth (see, e.g., Levine [28], Demirguc-Kunt and Maksimovic [11]). Hansmann [19] espouses a similar view of consumer protection laws in U.S. banking and insurance: He argues that their enactment made it unnecessary to use otherwise inefficient organizational forms that relied on consumer ownership to protect depositors and policyholders. Claimant protection laws here and elsewhere in the literature are viewed as essential Coasian property rights - public goods that enable efficient corporate organization by putting teeth into private contracts.

There is some dissent. Mayer and Franks [29] argue that investor protection does not explain the trend toward decentralized ownership in U.K. On the connection between law and growth, Allen, Qian, and Qian [1] cite the relative success of the "informal" sector in China as evidence that private alternatives can be effective substitutes for formal legal protections. Such private alternatives based on reputation and other informal mechanisms have 
been documented in other contexts (e.g., Greif [17], [18] and Bernstein [9]), and, to some extent, can be expected to circumvent shortcomings in the legal system. $^{1}$

The foregoing dissent is focused on the importance of legal protections rather than their nature, but a more sinister possibility is suggested by the work of Rajan and Zingales [35]. Their observation - that states may not enact law with an eye to promoting efficiency — raises the stakes considerably. If claimant protections result from Stiglerian interest group meddling rather than a benevolent assignment of Coasian property rights, we have good reason to question the social desirability of claimant protections. Indeed, stronger claimant protections - at least of the ilk passed at the behest of interest groups or misguided policymakers - may well be a hindrance to efficient organization and inimical to progress.

This paper studies these issues by examining the effects of claimant protection laws on the organizational composition of the U.S. life insurance market in the decades surrounding 1900. The period merits attention because it was one in which consumers could choose between regulated and

\footnotetext{
${ }^{1}$ Hay and Shleifer [21] acknowledge the use of private alternatives in countries with underdeveloped legal systems but argue that such mechanisms are likely to represent a second-best outcome.
} 
unregulated sectors of the market. The regulated sector, populated by legal reserve insurers (both stock and mutual), offered a high degree of state oversight. Policyholder interests were protected by a myriad of laws and auditing procedures, including deposit requirements, annual financial reports, annual valuations, periodic examinations, and various restrictions on market conduct. The unregulated sector consisted of fraternal insurers, which were exempt from regulation and from most of the fees and taxes that financed regulatory activities. Before 1900, fraternal policyholders could rely only on private alternatives to state protection, such as the reputation of the order and the strength of the bonds that bound its members. This changed in the early 1900's as fraternals came under the aegis of state regulation. Under the new regime, fraternals were subjected to many of the same laws theretofore applied to legal reserve companies. The transition period offers a unique opportunity to assess how claimant protection laws affected the organization of the insurance industry.

The evidence suggests a significant effect- - but a destructive one. As solvency regulations were applied to legal reserve companies in the latter half of the 19th century, the market share of the (unregulated) fraternal orders grew from nothing to more than $50 \%$ before 1900 . This spectacular rise was 
followed by an equally spectacular reversal of fortune that coincided with the extension of regulation to fraternal insurance. By the 1920's, fraternal market share had dropped below $10 \%$, and it would never recover.

The paper uses state-level data from 1899 to 1920 to show that fraternal insurer formation rates fell shortly after the adoption of solvency regulations. Little evidence is found to support other conventional explanations for the decline of the fraternal during this period. In particular, the rise of group insurance and the enactment of workers compensation laws appear to have played secondary roles in the decline of fraternal insurance before 1920. More tellingly, the increasing regulation of legal reserve companies during this period appears, if anything, to have delayed the decline of the fraternal.

Competitive fitness during this period seems to have been inversely related to the strength of claimant protections. When given a choice between regulated legal reserve companies and unregulated fraternal companies, the public, for better or for worse, often chose the latter. However, fraternal insurance declined after regulatory harmonization and was essentially unknown in the days before legal reserve companies were being regulated. This suggests that fraternal insurers may not have been more efficient than their legal reserve competitors to begin with: Although stronger state-provided 
claimant protections were not embraced by consumers, the circumvention by the private sector (in the form of fraternal insurance) seems likely to have been a costly second-best alternative.

The rest of this paper is organized as follows. Section 2 provides background on the fraternal order, other life insurance organizations, and their historical importance. It also discusses the legal context and the major regulatory developments of the period. Section 3.1 describes the data on organizational formations and regulation. Sections 3.2 and 3.3 present state-level empirical analyses of law changes, revealing that adoption of fraternal solvency regulations during the 1910's depressed fraternal order formation rates significantly — both in absolute terms and relative to legal reserve company formation rates - while other changes in the legal regime appear not to have contributed to the decline. Section 4 concludes and contemplates the implications of these findings in the broader context of the law and finance literature. 


\section{Background}

\subsection{Institutional Background}

Historically, the three major types of private life insurance providers in the U.S. have been stock companies, mutual companies, and fraternal orders. Stock and mutual companies are legal reserve institutions that use funds contributed in advance by policyholders (in the form of premiums) and by outside investors (in the form of capital or subordinated debt) to pay claims. Stock companies are owned and controlled by investors, while mutuals are owned and controlled by policyholders. Fraternal orders are nonprofit societies organized along ethnic, religious, or occupational lines that often operate on a lodge system. Most fraternals initially employed assessment insurance, a method based on post mortem collections (Kip [23], page 92), but some migrated toward legal reserve business practices over time. Ownership and control in fraternal insurers usually resided with the policyholders. ${ }^{2}$

The most well-known theoretical works on insurance organization (e.g.,

\footnotetext{
${ }^{2}$ This account glosses over more than a few details. Some legal reserve companies combined aspects of mutual and stock ownership; for example, some companies split the board of directors between policyholder appointees and investor appointees. Furthermore, although the vast majority of assessment insurance was written by fraternal orders, some assessment companies were proprietary. Moreover, ownership and control in fraternal orders were not always well-defined; some managers claimed significant ownership rights over the organizations they had founded.
} 
Mayers and Smith [30] and Hansmann [20]) focus on the tradeoffs between the stock and mutual forms of organization. Consumer ownership and control, stressed so heavily as the key sources of the mutual's strengths and weaknesses, were part of the foundation of the fraternal insurer as well. But the real schism between the fraternal insurer and other insurance companies derived from its assessment method of operation.

Unlike stock and mutual legal reserve companies companies, the pure fraternal assessment insurer did not collect premiums in advance. It did not establish reserves or hold assets. Legal reserve companies were required by law to hold sufficient financial assets to meet their outstanding liabilities and, in many cases, were required to secure those liabilities by making additional deposits with the state. The fraternal assessment insurer, on the other hand, was always technically insolvent. The fraternal contract's value depended on the order's ability to assess its membership. This ability was, in part, dependent on the cultural foundation of the order - the strength of the ties that bound its members and the order's ability to attract new members.

This is not to say that fraternal insurers were able to defy actuarial laws of gravity. Although orders employing assessment approaches were viable (see Emery [12]), assessment insurance could lead to failure when applied 
improperly. During the 1890 's, with failure clearly on the horizon, many orders found it necessary to depart from their egalitarian principles and grade their assessments according to mortality risk. Others went the extra step of establishing reserves. ${ }^{3}$ But there remained significant differences of degree and also of consequences: There was no annual valuation of fraternal insurers and no state intervention in the event of technical insolvency.

\subsection{Historical Context}

\subsubsection{Market Share}

Assessment insurance may have been practiced before 1868, but the emergence of fraternal assessment insurance is usually associated with the founding of the Ancient Order of United Workmen (AOUW) in that year. The subsequent success of fraternal life insurance is attributed to the public dissatisfaction with the high prices, suspect management, and inadequate forfeiture provisions offered by legal reserve companies at the time. In this environment, it is not surprising that inexpensive assessment insurance, as well as the catchy fraternal mantra ("Keep your reserve in your pocket!"),

\footnotetext{
${ }^{3}$ Beito [7], pp. 132-37.
} 
held such great appeal. ${ }^{4}$

The idea caught quickly. As shown in Figure 1,5 the latter quarter of the 19th century was one of rapid growth for fraternal insurance. At their peak in the 1890's, fraternal insurers had more than half the market despite having life operations that were virtually invisible 30 years earlier. The quick ascent was followed by a rapid decline in the early 1900's. A slip in market share between 1900 and 1910 morphed into a freefall. By 1930, fraternals had only $8 \%$ of the market.

The decade between 1910 and 1920 was especially disastrous for fraternal insurance. Fraternal life insurance in force shrank by $9 \%$ during this decade while total legal reserve insurance in force rose by $158 \%$. Moreover, industrial life insurance - a product marketed to lower income families that competed with fraternal insurance - in force rose by $126 \%{ }^{6}$ The divergent performance of fraternal and industrial life insurance during this period sug-

\footnotetext{
${ }^{4}$ For the mantra, see Kip [23], page 99. See Stalson [43] and Kip [23] for more discussion on the rise of the fraternals.

${ }^{5}$ Estimates exclude government and savings bank life insurance. Estimates for 1880 through 1910 are constructed using Stalson's Appendix 25, including assessment companies with fraternal orders. Estimates for 1940 and forward use ACLI figures for the total legal reserve life insurance in force in the U.S. and total life insurance in force in U.S. and Canadian fraternal societies. For 1915 through 1935, the Stalson figure is averaged with the ACLI figure. Comparison of the two estimates during this period revealed only small differences. Market share in 1870 is assumed to be zero (fraternal insurers started writing in 1869 , and the 1875 figure is based on interpolation between zero and the 1880 figure.

${ }^{6}$ These figures are based on Stalson's Appendices 25 and 26.
} 
gests a change in the environment that dramatically reduced the relative competitiveness of the fraternal insurer. While there are undoubtedly many environmental changes that may have contributed to the fraternal's decline, changing insurance regulation stands out as a likely primary culprit.

\subsubsection{Insurance Regulation}

Modern insurance regulation began with 1849 legislation in New York, which included a $\$ 100,000$ deposit requirement. The second half of the 19th century was a boom period for regulation. By 1868, 37 states were engaged in the supervision of insurance (Knight [24], page 157), and by the end of the century, all states were so engaged. States were free to regulate the in-state business of out-of-state companies as they saw fit, since the Supreme Court had judged insurance not to be commerce in Paul v. Virginia (1869).

The typical regulatory mix at the end of the 19th century included annual financial reports, annual valuation of life contract liabilities, minimum capital or deposit requirements, restrictions on investments (e.g., real estate investment was often limited to the company's offices), and some restrictions on policy terms. The state insurance commissioner was usually empowered to examine companies; in some states he was compelled to do so at a minimum 
frequency or upon the request of consumers or stockholders. If the company were found to be insolvent upon valuation or examination, the commissioner was compelled to take corrective action. Some states put controls on management compensation and restricted various forms of self-dealing, but this was unusual before the Armstrong Investigation of 1905.

Although the regulatory apparatus may have been highly developed by the standards of the time, the policyholder's dollar was not always being put to good use. Corruption and malfeasance in the industry was exposed forcefully by the Armstrong Investigation. In addition to recommending changes in oversight and various restrictions on management, the Armstrong Report encouraged the spread of mandatory contract provisions, such as nonforfeiture and incontestability clauses. These reforms addressed some of the shortcomings of legal reserve company operating practices and thus may have indirectly affected the competitive position of fraternal orders.

Fraternal insurance was also under direct assault by the regulators. Before 1900, fraternal orders faced minimal regulation. Under pressure from the states and established orders, the National Fraternal Congress (NFC) began to draft model regulations on solvency. In 1900, the NFC proposed the so-called "Force Bill," which addressed the most trenchant criticism of 
fraternal insurance - that it was not actuarially sound - by forcing new orders to operate on a legal reserve basis with rates from the NFC mortality table. However, it exempted established orders and engendered a bitter battle within the fraternal ranks. The roots of the battle stemmed from the threat posed by the new orders to those with aging memberships, especially in those orders that did not vary their assessments according to risk level (Beito [7], p. 137). More was to follow.

In 1910, a new model law, dubbed the Mobile Bill, was adopted by the National Association of Insurance Commissioners (NAIC) and promoted to the states. More comprehensive than the Force Bill, this law required annual valuations of all orders in addition to minimum rates for new orders. Established orders were not completely "off the hook." The bill provided for state intervention and other corrective measures if solvency standards were not met in the valuation. In particular if any order were revealed to be technically insolvent in its 1917 valuation, it would be compelled to adopt the minimum rates required of new orders if it did not show improvement on the next triennial valuation. The model bill underwent slight revisions, with its final incarnation being the New York Conference Bill (NYCB) of 1912 (Basye [6]). 
Figure 2 shows that fraternal solvency regulation was quickly enacted by the states in the 1910 's. ${ }^{7}$ In 1910 , only 13 states, representing less than $30 \%$ of the U.S. population, had a law requiring minimum rates or minimum valuations for fraternal orders. By 1920, 39 states, representing nearly $80 \%$ of the population, had such laws.

\subsubsection{Other Developments}

To be sure, there were other external influences that may have contributed to the decline of the fraternal life insurer during this period. In particular, group insurance and workers compensation laws were developments that threatened fraternal orders in the 1910's. Group insurance was not far behind the Force Bill in terms of the volumes of debate and vitriol produced in the Fraternal Monitor (Rochester, New York). On the other hand, group life insurance did not appear until 1915 and accounted for only $3 \%$ of total life insurance in force in 1920. The erosion in fraternal market share was clearly underway by 1915 , and $3 \%$ is only a sliver of the deterioration in fraternal market share

\footnotetext{
${ }^{7}$ Session laws and statute compilations for the 48 mainland states and the District of Columbia were reviewed over the 1898-1920 time period to find laws requiring fraternal orders to post minimum rates or meet valuation standards. Population estimates by state from the U.S. Bureau of the Census (taken at 10 year intervals) are used as weights, with logarithmic interpolation being used for unobserved years. The laws of Arkansas and Texas are counted here, which accounts for the slight discrepancies between the figure and Table 2.
} 
seen over the period. It seems unlikely that group insurance was the primary driver of the decline between 1910 and 1920 .

Workers' compensation laws also threatened the fraternal system on several levels. In addition to death benefits, many orders provided members with health benefits, accident benefits, and other forms of assistance. To varying degrees, responsibility for these benefits was shifted to employers by workers' compensation legislation. Fortunately, there is good data on the timing of workers' compensation enactments. As is shown in Section 3, they do not appear to have exerted a significant influence on fraternal life insurer formations once other factors are considered.

\section{Regulation and Fraternal Insurance}

This section documents the association between minimum rate regulations and the use of the fraternal form between 1899 and 1920. The first set of results demonstrates that the introduction of fraternal regulation was associated with a decrease in the absolute rate of fraternal insurer formation. The second set uses a pool of both fraternal and legal reserve company formations and models each formation as a choice between the fraternal form and the 
legal reserve form. The results show 1) the introduction of fraternal regulation was associated with a decrease in the popularity of the fraternal form, and 2) the popularity of the fraternal was, if anything, positively associated with stronger legal reserve company regulations.

The focus on formation rates instead of market share may seem unusual but is necessary for at least three reasons. First, market share data is not widely available on a state-level basis. Many state insurance departments did not collect and compile detailed statistical information on fraternal orders prior to the enactment of the Force Bill or the Mobile/NYCB legislation, rendering before-and-after comparisons impossible. Second, the market share impact of the legislation was likely to have been delayed as a result of the aforementioned grandfather clauses that granted existing orders temporary relief from the law's provisions. Finally, market share changes resulting from actions (e.g., adoption of minimum rates) by national orders are difficult to interpret in the context of individual state laws.

The case of Woodmen of the World provides an example of the latter two problems. Woodmen of the World, one of the largest fraternal insurers in the U.S. at the time, adopted NFC rates in 1919. This led to a drop of about $\$ 350$ million of in force insurance at Woodmen, which amounted to 
about $4 \%$ of total national fraternal insurance in force. While the conversion may indeed have been influenced by the valuation provisions on the books in certain states, Woodmen's writings in all states were affected. Moreover, the timing of the conversion may have been delayed relative to the adoption of fraternal regulation in the states due to the grandfather clauses.

\subsection{Data}

The dependent variable was constructed using "Directory of Fraternal Orders" section of the 1899 through 1930 editions of the Spectator [42] as the primary source. This lists information on fraternal orders by state, including the year organized. All orders determined to be formed between 1899 and 1920 were included in the analysis. If the Directory listed an order but omitted the "year organized" information, a secondary source (Fraternal Monitor [16]) was checked. If neither source had the relevant information, the order was not included in the analysis. Reports of state insurance departments (which were subject to availability) were also consulted with an eye to verifying the information in the other sources and picking up any orders that were missed. The latter source was especially useful for verifying organization year. Since fraternals were exempt from insurance department 
supervision in many states prior to the enactments studied in the paper, they had been operating for many years prior to being licensed. When both "year incorporated" and "year commenced" were available, the earlier date was chosen.

The fraternal law variables were constructed using session laws and statute compilations for the nature and timing of adoption for both the pre-1910 legislation and the Mobile/NYCB legislation. Both the Force Bill and the Mobile/NYCB legislation used the NFC mortality table as the basis for calculating minimum rates, and this was common across adopting states. The licensing, reporting, and exemption provisions, however, varied across states and, moreover, often departed significantly from prior practice. This poses a challenge for the empirical analysis.

Mobile/NYCB enactments typically exempted certain fraternal orders from all provisions of the law, including those requiring annual reports and licensing. In general, it is difficult to assess how many orders qualified under such exemptions, and to what extent the new laws contracted or expanded the organizational scope of state supervision with respect to licensing and reporting. Some states had exempted fraternal orders entirely from insurance laws prior to enacting minimum rate legislation. In these states, the scope 
clearly expanded, and our knowledge of existing fraternal orders and the formation of new orders improved with the enactment. Such improvement in knowledge will tend to bias the methodology against finding a negative effect associated with the enactment because our ability to observe new formations is better in the years after the enactment than in those before the enactment. On the other hand, some states had reporting and licensing requirements for fraternal orders before enacting minimum rate legislation. The scope in these states could have changed in either direction, depending on how the new exemption provision compared with any provision that it replaced. Thus, in these states, the bias could operate in either direction. While no general fix was found for this issue, the state insurance department reports revealed three "problem" states that needed special attention: Massachusetts, Arkansas, and Texas.

Massachusetts' 1901 enactment had a typical exemption provision for associations "not on the lodge system" or any limiting its membership to "employees of towns or cities, or of the Commonwealth, or of the federal government, or of a designated firm ... or to persons of the same occupation." However, unlike other states that granted similar exemptions, Massachusetts required reports of such associations. The latitude was widely utilized, with 
dozens of fraternal orders being formed each year under the exemption provisions of the Massachusetts code. Accordingly, the Annual Report of the Insurance Commissioner of the Commonwealth of Massachusetts was consulted to identify orders which were operating on the lodge system and subject to the provisions of the laws passed in 1901 and 1911. Only those orders on the lodge system were included in the analysis.

Arkansas' enactment of 1917 was not unusual, but the Insurance Commissioner chose not to enforce the statute in the case of fraternal societies that served blacks. As described in the Arkansas Insurance Report for 1917 (p. 29), "...the Department has maintained a rather tolerant attitude..." toward such orders. The forbearance appears to have been phased out by the early 1920's, but a number of black-only fraternal societies were formed in the intervening years. Due to this apparent gap in enforcement and our inability to distinguish black-only orders from white-only orders in the earlier years of the sample, Arkansas orders are excluded.

Texas offers a different problem. Dozens of fraternal insurer formations were recorded between 1899 and 1907, but the Departments stopped recording the organization dates of fraternal orders in its 1908 Texas Insurance Report. Moreover, legislation in 1909 shuffled organizational definitions, and a 
number of organizations formerly classified as "fraternal associations" were reclassified as "local mutual aid associations," with new fraternal formations being documented according to the new definitions. Because of our inability to properly and completely categorize earlier formations according to the classification system after 1909, as well as the lack of data on organization dates, Texas orders are excluded.

Controls for workers' compensation laws and legal reserve life insurance regulations are also included. The variable for workers' compensation law enactments is installed using the dates reported in Fishback and Kantor [15]. Table 1 describes a set of important insurance regulations, many of them proposed by the Armstrong Committee. The enactment dates of these laws were determined using statute compilations and session laws for the 48 states and the District of Columbia. ${ }^{8}$ The regulations concern a variety of monitoring and auditing duties assigned to the commissioner, bonding requirements (in the form of deposits or minimum capital), restrictions on company behavior, and rules regarding the policy forms issued to consumers. Various strategies are used to facilitate the empirical analysis of this large number of laws, including indexing, dummies for multiple laws, and single variable dummies

\footnotetext{
${ }^{8}$ See Zanjani [44] for details on the collection of these data.
} 
indicating the dates of major reform enactments. These are described in detail in the "Constructed" section of the Table.

Legal reserve company incorporation data (used in Section 3.3) was collected from annual issues of the Spectator from 1900 to 1952. The lesser of "year incorporated" and "year commenced" was taken as the formation date. Only fresh incorporations were used; conversions by assessment companies or fraternal orders, as well as reincorporations by existing legal reserve companies, were excluded.

Table 2 presents summarized data on company formations and law enactments by year. Fraternal life insurer formations were evidently more frequent in the first decade of the 20th century than the second, both in absolute terms and relative to legal reserve insurer formations. The table also shows rich variation in the timing of minimum rate law adoption. Although the bulk of the states adopted between 1910 and 1915, nine states adopted before 1905, four states adopted between 1906 and 1910, and nine states (as well as the District of Columbia) never adopted during the sample period. However, the table reveals that it may be difficult to establish a connection between the enactment of minimum rate laws and the decline of fraternal formations because of the contemporaneous enactments of workers' compensation statutes 
and Armstrong reforms.

\subsection{Results on Formation Rates}

We first examine the association between laws and fraternal insurer formation rates. The dependent variable in the analysis, $y_{i t}$, is the number of fraternal orders formed in state $i$ in year $t$. The independent variables are state indicators (for all states and the District of Columbia with at least one fraternal order formation between 1899 and 1920), year indicators, an indicator variable taking a value of one if the state had adopted minimum rate legislation in a previous year and zero otherwise, and similar indicators for the presence of workers' compensation laws and other insurance regulations. In some specifications, indices of "other insurance regulations" are used in place of indicators.

The Poisson regression model is used for the analysis:

$$
\operatorname{Pr}\left(\mathbf{Y}_{i t}=y_{i t}\right)=N_{i t} \frac{e^{-\lambda_{i t}} \lambda_{i t}^{y_{i t}}}{y_{i t} !}
$$

where $\ln \lambda_{i t}=\mathbf{x}_{i t}^{\prime} \mathbf{b}, \mathbf{x}_{i t}$ is the matrix of the explanatory variables, and $N_{i t}$ is an population estimate for state $i$ in year $t \cdot{ }^{9}$ Table 3 shows the variables and

\footnotetext{
${ }^{9}$ Population estimates by state for 1890, 1900, 1910 and 1920 were taken from the U.S.
} 
population-weighted means, and Tables 4 and 5 present parameter estimates and implied effects. Three major aspects of the results merit discussion.

First and foremost, the evidence shows an association between the enactment of minimum rate legislation and a decrease in the formation rates of fraternal life insurers. The estimates are statistically and economically significant (except in the case of the Force Bill). As can be seen in Table 4, estimates of the Force Bill's effect are in the neighborhood of -30\%; estimates of the Mobile Bill's effect are in the neighborhood of $-60 \%$; estimates of the effect of any minimum rate law are in the neighborhood of $-45 \%$.

Second, the formation rates exhibit a negative time trend. Negative and statistically significant year effects (relative to the reference year of 1899) appear with consistency after 1910 and are considerably lower in the 1910's than the 1900's. Moreover, the year effects are larger in absolute magnitude than effects associated with the laws, suggesting a role for unspecified environmental changes in the decline of the fraternal. What exactly those changes were, and to what extent they were driven by changes in legal environment, cannot be ascertained with certainty. But at least some of it may be attributed to effects of fraternal legislation that were being felt beyond the

Bureau of the Census. Logarithmic interpolation was used to generate estimates for the other years in the sample. 
borders of the enacting states. Many fraternal orders were enterprises defined not by state borders, but by the ethnic, occupational, or religious ties that bound their members. Regulation, however, applied by state of operation rather than state of domicile. The prospects for expansion of a new order, or the introduction of a life insurance department to an existing national order, would thus be seriously affected by the explosion of regulation that occurred in the 1910's - even if regulation in the state of domicile (where the headquarters is located) were nonexistent. Of course, we cannot be sure that the negative year effects were driven by fraternal legislation and not Armstrong or workers' compensation legislation. For example, the drop in year effects in 1911 coincides neatly with a surge in Mobile enactments - and a surge in workers' compensation enactments, as can be seen in Table 2. On the other hand, if the workers' compensation or Armstrong legislation were having a negative influence beyond the borders of the enacting states, it is hard to explain why the estimates of these laws' effects within enacting states do not show a similar influence.

Third, as noted above, the tables show no compelling evidence that the other laws studied had any association with the decline in fraternal formations. The "Workers' Compensation" coefficient is positive (a result contrary 
to expectations) but insignificant. The "Minimum Capital" coefficient is positive and, in one specification, statistically significant; this influence is consistent with the evidence found by Zanjani [44] in the legal reserve market. The evidence on legal reserve regulations more generally is inconclusive. The "Armstrong" coefficient is negative and insignificant, but the "Index" coefficients suggest that more regulation may have encouraged fraternal formations. The specifications that break out individual insurance laws suggest a mixed bag of effects, with some evidence that laws regarding oversight and the restriction of company expenses may have encouraged fraternal formation. To address the possibility of collinearity in the law variables, Table 5 presents estimates based on running the model, one law at a time. This test does not change the basic results and appears to strengthen the case for fraternal legislation being the key law change associated with the drop in fraternal formation rates.

\subsection{Results on the Choice of Form}

The analysis to this point has focused on the response of fraternal order formations to changes in regulation. An alternative approach views fraternal

formations more broadly as reflecting a choice between the regulatory regime 
for legal reserve companies and the regulatory regime for fraternal orders. Did the industry substitute toward the legal reserve forms in the wake of the changes in the early 20th century? Or, put differently, was new life insurance demand met with new fraternal companies or new legal reserve companies?

This section adds data on legal reserve company formations by state and uses the logit specification to model each company formation as a choice between the fraternal and legal reserve forms. The dependent variable takes a value of one if the fraternal form was chosen and zero otherwise:

$$
\operatorname{Pr}\left(\mathbf{Y}_{i t}=1\right)=\frac{e^{\mathbf{x}_{i t}^{\prime} \mathbf{b}}}{1+e^{\mathbf{x}^{\prime} t^{\mathbf{b}}}} .
$$

The sample statistics and results, presented in Tables 6 through 8, largely mirror those presented in Section 3.2. In interpreting the results, the exercise is similar to that in the preceding section. "Enabling" laws that regulate fraternals will have a positive effect on fraternal form popularity, while "disabling" laws that regulate fraternals will have a negative effect. Conversely, laws that enable legal reserve companies should have a negative effect on fraternal form popularity, while laws that disable legal reserve companies should have a positive effect. The results are directionally similar to the preceding section, with a few differences worthy of note. 
The evidence reiterates the association between the enactment of fraternal legislation and a decline in the use of the fraternal form. In this case, the decline in use is measured relative to use of the legal reserve form. As can be seen in Table 7 , they are similar in direction to the estimates in Table 4, with a few differences. A larger effect is associated with the Force Bill than the Mobile Bill, with the latter estimates failing the usual tests for statistical significance: This is the reverse of the findings in Table 4

The evidence on other laws, as seen in Tables 7 and 8, again fails to find a connection with the decline of the fraternal. Workers' compensation laws do not appear to have negatively affected propensity to choose the fraternal form. The association between minimum capital requirements and choice of the fraternal form is positive, but does not meet the usual standards for statistical significance. The evidence regarding other insurance legislation is, again, mixed; taken as a whole, however, the estimates suggest that the relative popularity of the fraternal insurer tended to increase with more legal reserve regulations.

The year effects suggest a negative time trend in the relative popularity of the fraternal form, but starting as early as 1905. Moreover, the year effects for 1907-1910 are comparable to those seen in the 1911-1920 period. 
Thus, an apparent dropoff in fraternal popularity appears earlier than seen in the Poisson regressions. This may reflect spillover from the Armstrong legislation and investigation. Unlike the fraternal legislation, Armstrong legislation did not offer grandfather clauses. Moreover, the investigation tainted the reputations of some of the largest national companies. This may have created opportunities for new legal reserve companies that were unsullied by the investigation, as well as new companies in states that had not enacted Armstrong legislation (if Armstrong legislation in fact was a burden for le-

gal reserve companies, as is suggested by the results discussed above). To the extent that new legal reserve companies were better substitutes for consumers that had already chosen the legal reserve regime, it is plausible that the relative popularity of the fraternal form would appear to fall in states that had not yet enacted Armstrong legislation.

\section{Summary and Conclusion}

This paper studied the effects of consumer protection laws on organizational form in life insurance. The historical record does not support an enabling view of consumer protection laws. Fraternal insurance, the unregulated alter- 
native to production under consumer protection regulation, grew quickly in the late 19th century. Fraternal insurers declined in importance after being subjected to solvency regulation in the early 20th century. There may have been a number of factors contributing to the fraternal's decline, but the evidence presented in the paper suggests that regulation was not an enabler of fraternal insurance, regardless of whether or not it served the public interest.

Fraternals relied on the informal bonds among their membership to sustain an assessment insurance program, and any advantages in this approach disappeared with legislation that effectively prohibited assessment insurance. However, while their model was successful in the late 19th century, fraternal orders may never have been the ideal delivery vehicle for life insurance. Indeed, the timing of its ascent suggests that fraternal insurance was a response to problems that developed in the life industry, and its regulatory exemption may well have been integral to its success. Fraternal orders date at least to early 18th century in North America, but they were unimportant in life insurance until the 1870 's - more than 25 years after the birth of the modern version of the industry in 1843. Regulators may have planted the seeds for fraternal growth with legal reserve regulations in the 1850's and 1860's, but they salted the fields in the early 1900's with minimum rate legislation. 
The ensuing decline in the competitiveness of the fraternal life insurance product may have played a key role in the general decline in fraternal membership that was to occur later in the 20th century, just as the emergence of the product may have played a key role in the membership boom of the late 19th century. While the causality, of course, could be argued to flow in the other direction, this paper has provided some evidence for the former view.

More generally, this experience illustrates that claimant protection laws are not an unmitigated blessing. Such laws can constrain relationships as well as enable them. In the case of life insurance, the ex ante bonding and other precautions required in most states may have been either excessive or not well-matched to the technologies of the time. Arrangements built on reputation and other informal considerations, without explicit bonding or state oversight, appear to have outperformed the regulated industry. While such mechanisms are often cast as alternatives when the legal system is underdeveloped, the experience with the fraternals shows that such mechanisms, where available, may also be preferable in situations where legal protections are overdeveloped or burdensome. It easy to imagine situations where "public interest" is not the primary driver of regulation: As noted earlier, the fraternal reform movement derived, in part, from the machinations of vested 
interests. The non-monotonic relationship between efficiency and claimant protections, the reasons behind their enactment, and the extent to which private activity can circumvent any weaknesses in the legal system, seem to be fruitful areas for future research. 


\section{References}

[1] Allen, F., Qian, J., and Qian, M. (2002), "Law, Finance, and Economic Growth in China," working paper, Wharton.

[2] A.M. Best Company (various years), Best's Aggregates \&6 Averages: LifeHealth. Oldwick: A.M. Best Company.

[3] A.M. Best Company (various years), Best's Aggregates 86 Averages: Property-Casualty. Oldwick: A.M. Best Company.

[4] A.M. Best Company (various years), Best's Insurance Reports, LifeHealth Oldwick: A.M. Best Company.

[5] American Council of Life Insurance (various years), Life Insurance Fact Book ACLI.

[6] Basye, W. (1919), History and Operation of Fraternal Insurance. Rochester: The Fraternal Monitor.

[7] Beito, D.T. (2000), From Mutual Aid to the Welfare State: Fraternal Societies and Social Services, 1890-1967. Chapel Hill and London: The University of North Carolina Press.

[8] Bernheim, B.D. (1987), "A Theoretical Analysis of Economic Organization in the Life Insurance Industry," Center for Economic Policy Research Publication \#133.

[9] Bernstein, L. (1992), "Opting Out of the Legal System: Extralegal Contractual Relations in the Diamond Industry," Journal of Legal Studies 21, $115-57$.

[10] Buley, R.C. (1953), The American Life Convention 1906-1952: A Study in the History of Life Insurance New York: Appleton-Century-Crofts.

[11] Demirguc-Kunt, A. and Maksimovic, V. (1998), "Law, Finance, and Firm Growth," Journal of Finance 53, 2107-37.

[12] Emery, J.C.H. (1993), "The Rise and Fall of Fraternal Methods of Social Insurance: A Case Study of the Independent Order of Oddfellows of British Columbia," doctoral dissertation, University of British Columbia. 
[13] Fama, E.F., and Jensen, M.C. (1983), "Separation of Ownership and Control," Journal of Law and Economics 26, 301-25.

[14] Fama, E.F., and Jensen, M.C. (1983), "Agency Problems and Residual Claims," Journal of Law and Economics 26, 327-49.

[15] Fishback, P.V., and Kantor, S.E. (1998), "The Adoption of Workers' Compensation in the United States, 1900-1930," Journal of Law and Economics 41, 305-41.

[16] Fraternal Monitor (various years) Statistics, Fraternal Societies Rochester: Fraternal Monitor.

[17] Greif, A. (1989), "Reputation and Coalitions in Medieval Trade: Evidence on the Maghribi Traders," Journal of Economic History 49, 857882 .

[18] Greif, A. (1993), "Contract Enforceability and Economic Institutions in Early Trade: The Maghribi Traders' Coalition," American Economic Review 83, 525-548.

[19] Hansmann, H. (1996), The Ownership of Enterprise Cambridge and London: The Belknap Press of Harvard University Press.

[20] Hansmann, H. (1985), "The Organization of Insurance Companies: Mutual versus Stock," Journal of Law, Economics, and Organization 1, 125153.

[21] Hay, J.R., and Shleifer, A. (1998), "Private Enforcement of Public Laws: A Theory of Legal Reform," American Economic Review 88 (2), 398-403.

[22] Himmelberg, C.P., Hubbard, R.G., and Love, I. (2002), "Investor Protection, Ownership, and the Cost of Capital," working paper, Columbia University.

[23] Kip, R.D.R. (1953), Fraternal Life Insurance in America Philadelphia: College Offset Press.

[24] Knight, C.K. (1920), The History of Life Insurance in the United States to 1870 doctoral thesis, University of Pennsylvania. 
[25] La Porta, R., Lopez-de-Silanes, F., Shleifer, A., and Vishny, R. (2000), "Investor Protection and Corporate Governance," Journal of Financial Economics 58, 3-27.

[26] La Porta, R., Lopez-de-Silanes, F., Shleifer, A., and Vishny, R. (1999), "Corporate Ownership Around the World," Journal of Finance 54, 471517.

[27] La Porta, R., Lopez-de-Silanes, F., Shleifer, A., and Vishny, R. (1998), "Law and Finance," Journal of Political Economy 106, 1113-1155.

[28] Levine, R. (1999), "Law, Finance, and Economic Growth," Journal of Financial Intermediation 8 (1-2), 36-67.

[29] Mayer, C., and Franks, J. (2003), "The Origination and Evolution of Ownership and Control," CEPR Discussion Paper 3822.

[30] Mayers, D. and Smith, C.W. (1981), "Contractual Provisions, Organizational Structure, and Conflict Control in Insurance Markets," Journal of Business 54, 407-34.

[31] Meier, K.J. (1988), The Political Economy of Regulation: The Case of Insurance Albany: State University of New York Press.

[32] NAIC (1999), NAIC Compendium of State Laws on Insurance Topics Kansas City: NAIC.

[33] National Fraternal Congress (various years), Proceedings Madison: NFC.

[34] Nichols, W.S. (1877), "Annals of American Insurance, 1721-1876," in Insurance Blue Book, Centennial Issue New York: C.C. Hine.

[35] Rajan, R., and Zingales, L. (2003), "The Great Reversals: The Politics of Financial Development in the Twentieth Century," Journal of Financial Economics, forthcoming.

[36] Remmers, B. (2000), "Viability of the Mutual Organizational Form," mimeo, Stern School of Business.

[37] Shleifer, A., and Wolfenzon, D. (2000), "Investor Protection and Equity Markets," Journal of Financial Economics 66, 3-27. 
[38] Smith, B.D., and Stutzer, M. (1995), "A Theory of Mutual Formation and Moral Hazard with Evidence from the History of the Insurance Industry," Review of Financial Studies 8, 545-577.

[39] Smith, B.D., and Stutzer, M. (1990), "Adverse Selection, Aggregate Uncertainty, and the Role for Mutual Insurance Contracts," Journal of Business 63, 493-510.

[40] Spectator Company (1911), Life Insurance History 1843-1910 New York and Chicago: Spectator Company.

[41] Spectator Company (various years), Insurance Year Book: Fire and Marine New York, Chicago, and Philadelphia: Spectator Company and Chilton Company.

[42] Spectator Company (various years), Insurance Year Book: Life New York, Chicago, and Philadelphia: Spectator Company and Chilton Company.

[43] Stalson, J.O. (1969), Marketing Life Insurance: Its History in America Homewood: Richard D. Irwin, Inc.

[44] Zanjani, G. (2003), "Regulation, Capital, and Organizational Form in U.S. Life Insurance," working paper, Federal Reserve Bank of New York. 


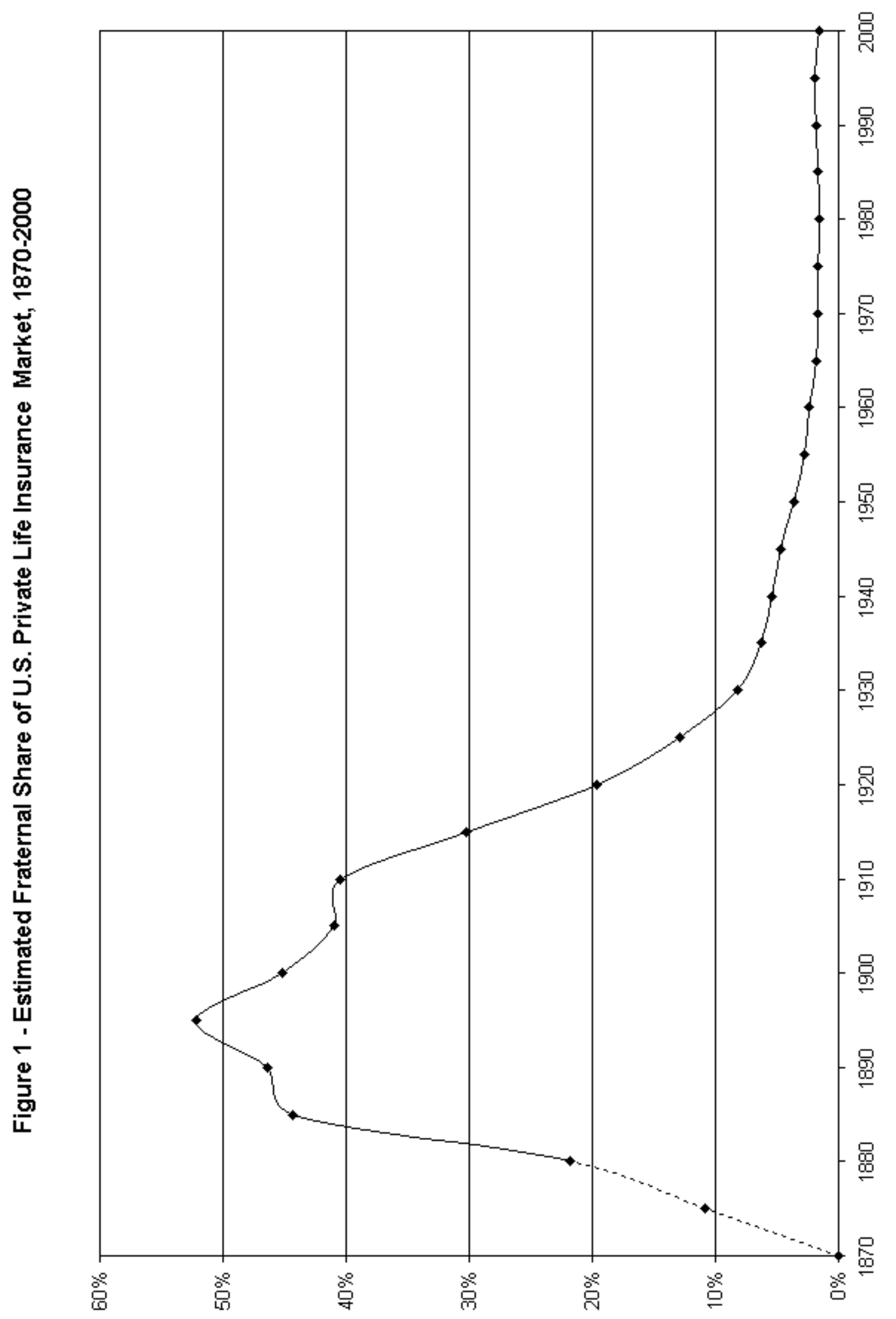




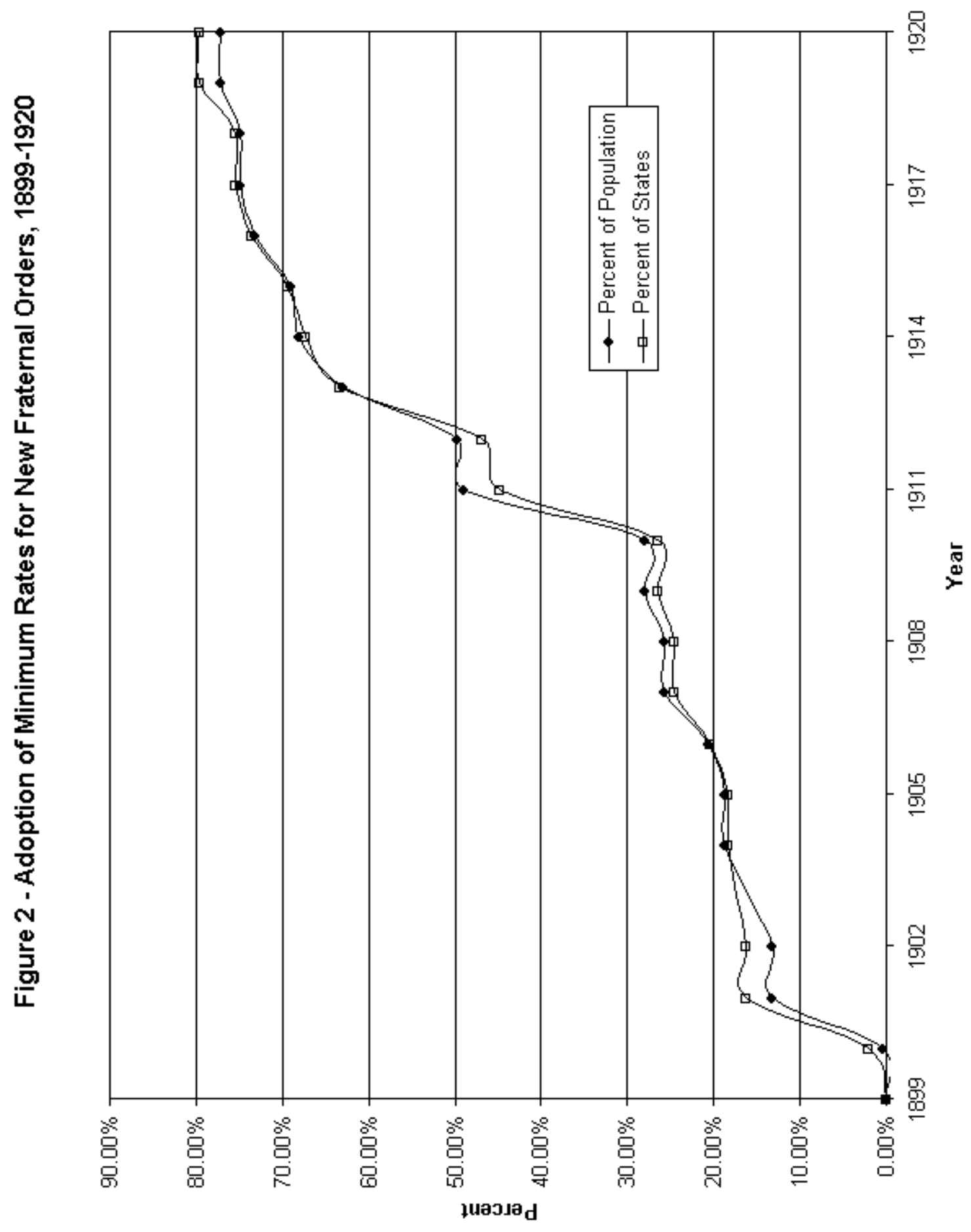




\begin{tabular}{|c|c|c|}
\hline \multicolumn{3}{|c|}{ Table 1 - Descriptions of Insurance Laws } \\
\hline Law & Description & $\begin{array}{c}\text { Armstrong } \\
\text { Reform? }\end{array}$ \\
\hline \multicolumn{3}{|l|}{ Oversight } \\
\hline Annual Statement & Company obliged to provide annual report of financial condition and operations & No \\
\hline Valuation & Commissioner obliged to make periodic valuation of company liabilities and assets & Yes \\
\hline Examination & Commissioner empowered to examine the affairs of any licensed company & No \\
\hline Voucher & Company obliged to establish voucher for any disbursement over a given sum & Yes \\
\hline Valuation Deposit & Company required to deposit assets to cover liabilities & No \\
\hline \multicolumn{3}{|l|}{ Policy } \\
\hline Review & New policy forms must be filed with commissioner & Yes \\
\hline Rebates & Rebating and price discrimination forbidden & Yes \\
\hline Incontestability & Policy incontestable after a fixed period of time & Yes \\
\hline Nonforfeiture & Ordinary life policies required to contain nonforfeiture provisions & Yes \\
\hline \multicolumn{3}{|l|}{ Conduct } \\
\hline Investments & Any law restricting the types of financial asset holdings & Yes \\
\hline Dividend & Stockholder dividends allowed only out of surplus earnings & No \\
\hline Political & Political contributions forbidden & Yes \\
\hline Self-Dealing & $\begin{array}{l}\text { Any law forbidding loans to employees or owners, or barring employees from receiving } \\
\text { compensation for negotiating an investment purchase or sale }\end{array}$ & Yes \\
\hline Compensation & Limits on pensions, bonuses, or contingent compensation for officers & Yes \\
\hline Other Expense & Limits on acquisition or policy expenses & Yes \\
\hline \multicolumn{3}{|l|}{ Board Involvement } \\
\hline Salary & Salaries in excess of a specified sum must be approved by board of directors & Yes \\
\hline Authorization & Investments must be authorized by board of directors & Yes \\
\hline \multicolumn{3}{|l|}{ Other } \\
\hline Force & Circa 1901. Minimum rates required for new societies & No \\
\hline Mobile & Circa 1911. Required minimum rates for new societies and, in most cases, & No \\
\hline & valuations for both new and old societies & No \\
\hline Minimum Capital & Initial capital, assets, or deposit required to start a legal reserve company & No \\
\hline Workers' Comp & Workers' compensation law - Mandatory insurance & No \\
\hline \multicolumn{3}{|l|}{ Constructed } \\
\hline Armstrong & State has implemented at least three Armstrong reforms subsequent to 1905 & - \\
\hline Basic Oversight & Annual Statement + Examination + Valuation (all three) & - \\
\hline Basic Policy & Review + Rebates + Incontestability + Nonforfeiture (all four) & - \\
\hline Basic Conduct & Investments + Dividend + Self-Dealing (all three) & - \\
\hline Board & Salary or Authorization & - \\
\hline Minimum Rate & Force or Mobile & - \\
\hline Oversight Index & Total number of "Oversight" laws in place & - \\
\hline Conduct Index & Total number of "Conduct" laws in place & - \\
\hline Policy Index & Total number of "Policy" laws in place & - \\
\hline
\end{tabular}




\begin{tabular}{|c|c|c|c|c|c|}
\hline \multicolumn{6}{|c|}{$\begin{array}{c}\text { Table } 2 \text { - Laws and Company Formations, 1899-1920 } \\
\text { (excluding Texas and Arkansas) }\end{array}$} \\
\hline Year & $\begin{array}{l}\text { Fraternal } \\
\text { Formations }\end{array}$ & $\begin{array}{l}\text { Legal Reserve } \\
\text { Formations }\end{array}$ & $\begin{array}{l}\text { States with } \\
\text { Minimum Rates } \\
\text { for Fraternals }\end{array}$ & $\begin{array}{c}\text { States with } \\
\text { Workers' Comp } \\
\text { Laws }\end{array}$ & $\begin{array}{l}\text { States enacting } \\
\text { at least three } \\
\text { Armstrong Reforms }\end{array}$ \\
\hline 1899 & 76 & 6 & 0 & 0 & 0 \\
\hline 1900 & 48 & 4 & 1 & 0 & 0 \\
\hline 1901 & 61 & 5 & 8 & 0 & 0 \\
\hline 1902 & 86 & 7 & 8 & 0 & 0 \\
\hline 1903 & 70 & 9 & 8 & 0 & 0 \\
\hline 1904 & 62 & 9 & 9 & 0 & 0 \\
\hline 1905 & 62 & 20 & 9 & 0 & 0 \\
\hline 1906 & 96 & 37 & 10 & 0 & 2 \\
\hline 1907 & 47 & 31 & 12 & 0 & 16 \\
\hline 1908 & 53 & 23 & 12 & 0 & 17 \\
\hline 1909 & 43 & 40 & 13 & 0 & 23 \\
\hline 1910 & 51 & 26 & 13 & 1 & 23 \\
\hline 1911 & 35 & 19 & 22 & 11 & 25 \\
\hline 1912 & 22 & 11 & 24 & 14 & 25 \\
\hline 1913 & 29 & 10 & 30 & 21 & 29 \\
\hline 1914 & 14 & 13 & 32 & 23 & 29 \\
\hline 1915 & 12 & 6 & 33 & 31 & 29 \\
\hline 1916 & 18 & 11 & 35 & 31 & 30 \\
\hline 1917 & 20 & 12 & 35 & 36 & 30 \\
\hline 1918 & 8 & 4 & 35 & 37 & 30 \\
\hline 1919 & 6 & 21 & 37 & 41 & 31 \\
\hline 1920 & 15 & 14 & 37 & 41 & 31 \\
\hline
\end{tabular}




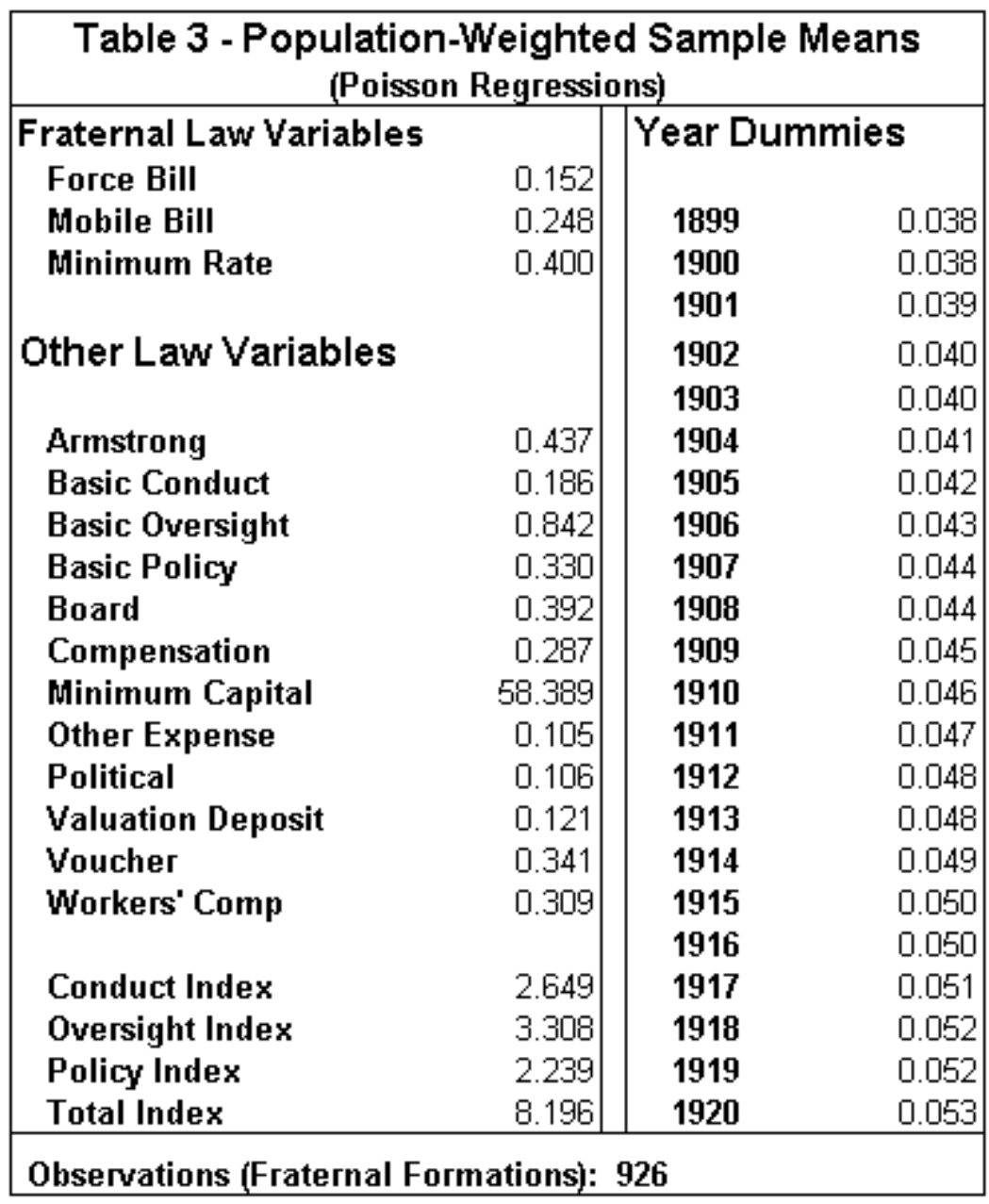




\begin{tabular}{|c|c|c|c|c|c|c|}
\hline \multicolumn{7}{|c|}{$\begin{array}{c}\text { Table } 4 \text { (Part 1) - Parameter Estimates and Implied Formation Rate Changes } \\
\text { for Poisson Model of Fraternal Insurer Formations }\end{array}$} \\
\hline & (1) & (2) & (3) & (4) & (5) & (6) \\
\hline Force & $\begin{array}{l}-0.4146 \\
(0.3453)\end{array}$ & $\begin{array}{l}-0.3696 \\
(0.3451)\end{array}$ & $\begin{array}{l}-0.4188 \\
(0.3476)\end{array}$ & - & - & - \\
\hline Mobile & $\begin{array}{l}-1.0257^{*} \\
(0.3825)\end{array}$ & $\begin{array}{l}0.8971^{\not t} \\
(0.3498)\end{array}$ & $\begin{array}{l}-1.0659^{\circ} \\
(0.3806)\end{array}$ & - & - & - \\
\hline Minimum Rate & - & - & - & $\begin{array}{l}\mathbf{0 . 6 3 7 5} \\
(0.2231)\end{array}$ & $\begin{array}{l}-0.5562^{+*} \\
(0.2504)\end{array}$ & $\begin{array}{l}\mathbf{0 . 6 5 2 4} \\
(0.2366)\end{array}$ \\
\hline Workers' Comp & $\begin{array}{l}0.2711 \\
(0.3057)\end{array}$ & $\begin{array}{c}0.2238 \\
(0.2697)\end{array}$ & $\begin{array}{l}0.2499 \\
(0.3219)\end{array}$ & $\begin{array}{c}0.3029 \\
(0.3001)\end{array}$ & $\begin{array}{c}0.2415 \\
(0.2596)\end{array}$ & $\begin{array}{c}0.2610 \\
(0.3026)\end{array}$ \\
\hline Armstrong & $\begin{array}{l}-0.0661 \\
(0.2293)\end{array}$ & - & - & $\begin{array}{l}-0.0749 \\
(0.2299)\end{array}$ & - & - \\
\hline Minimum Capital & $\begin{array}{c}0.0026 \\
(0.0018)\end{array}$ & $\begin{array}{c}0.0044 \\
(0.0033)\end{array}$ & $\begin{array}{c}0.0013 \\
(0.0029)\end{array}$ & $\begin{array}{c}\mathbf{0 . 0 0 3 2} \\
(0.0018)\end{array}$ & $\begin{array}{c}0.0048 \\
(0.0033)\end{array}$ & $\begin{array}{c}0.0019 \\
(0.0032)\end{array}$ \\
\hline Basic Oversight & - & $\begin{array}{c}\mathbf{0 . 6 8 2 4} \\
(0.2644)\end{array}$ & - & - & $\begin{array}{c}\mathbf{0 . 6 2 3 0} \\
(0.2799)\end{array}$ & - \\
\hline Valuation Deposit & - & $\begin{array}{l}-0.1054 \\
(0.4478)\end{array}$ & - & - & $\begin{array}{l}-0.0449 \\
(0.4506)\end{array}$ & - \\
\hline Voucher & - & $\begin{array}{l}-0.1126 \\
(0.4162)\end{array}$ & - & - & $\begin{array}{l}-0.0832 \\
(0.4312)\end{array}$ & - \\
\hline Basic Conduct & - & $\begin{array}{l}-0.4993 \\
(0.3280)\end{array}$ & - & - & $\begin{array}{l}-0.5389 \\
(0.3453)\end{array}$ & - \\
\hline Other Expense & - & $\begin{array}{c}\mathbf{0 . 6 4 9 0} \\
(0.3583)\end{array}$ & - & - & $\begin{array}{c}0.6972^{=} \\
(0.3480)\end{array}$ & - \\
\hline Compensation & - & $\begin{array}{c}0.5227^{*} \\
(0.2644)\end{array}$ & - & - & $\begin{array}{c}\mathbf{0 . 6 3 1 4} \\
(0.2821)\end{array}$ & - \\
\hline Board & - & $\begin{array}{l}-0.1346 \\
(0.3459)\end{array}$ & - & - & $\begin{array}{c}-0.1378 \\
(0.3623)\end{array}$ & - \\
\hline Political & - & $\begin{array}{l}-0.2413 \\
(0.3079)\end{array}$ & - & - & $\begin{array}{c}-0.2806 \\
(0.3533)\end{array}$ & - \\
\hline Basic Policy & - & $\begin{array}{c}0.0712 \\
(0.3827)\end{array}$ & - & - & $\begin{array}{l}-0.0078 \\
(0.4078)\end{array}$ & - \\
\hline Oversight Index & - & - & $\begin{array}{c}\mathbf{0 . 2 0 8 5} \\
(0.1138)\end{array}$ & - & - & $\begin{array}{c}\mathbf{0 . 1 8 9 4} \\
(0.1145)\end{array}$ \\
\hline Policy Index & - & - & $\begin{array}{c}0.0482 \\
(0.1014)\end{array}$ & - & - & $\begin{array}{c}0.0599 \\
(0.1141)\end{array}$ \\
\hline Conduct Index & - & - & $\begin{array}{l}-0.0067 \\
(0.1081)\end{array}$ & - & - & $\begin{array}{l}-0.0072 \\
(0.1145)\end{array}$ \\
\hline \multicolumn{7}{|c|}{ Implied Percentage Change in Fraternal Formation Rate Due To Law Enactments } \\
\hline Force Bill & $-34 \%$ & $-31 \%$ & $-34 \%$ & - & - & - \\
\hline Mobile Bill & $-64 \%$ & $-59 \%$ & $-66 \%$ & - & - & - \\
\hline Minimum Rate Law & - & - & - & $-47 \%$ & $-43 \%$ & $-48 \%$ \\
\hline $\begin{array}{l}\text { Notes: Standard errors } \\
90 \% \text { and } 95 \% \text { levels is } \\
\text { calculated using samp } \\
\text { to present (1) in estim }\end{array}$ & $\begin{array}{l}\text { bust to } 0 \\
\text { dicated } \\
\text { means fo }\end{array}$ & $\begin{array}{l}\text { by stat } \\
\text { d , resp } \\
\text { ables ex }\end{array}$ & $\begin{array}{l}\text { I0wn in p } \\
\text { Implie } \\
\text { law in } 0\end{array}$ & $\begin{array}{l}\text { leses. St } \\
\text { iges in } \mathrm{fr} \\
\mathrm{n} \text {, which }\end{array}$ & $\begin{array}{l}\text { al significa } \\
\text { I formatior } \\
\text { anged from }\end{array}$ & $\begin{array}{l}\text { at the } \\
\text { s are } \\
\text { ent (0) }\end{array}$ \\
\hline
\end{tabular}




\begin{tabular}{|c|c|c|c|c|c|c|}
\hline & \multicolumn{5}{|c|}{$\begin{array}{l}\text { Table } 4 \text { (Part 2) - Parameter Estimates of Year Effects } \\
\text { for Poisson Model of Fraternal Insurer Formations }\end{array}$} & \multirow[b]{2}{*}{ (6) } \\
\hline & (1) & (2) & (3) & (4) & (5) & \\
\hline 1900 & $\begin{array}{l}\mathbf{0 . 4 8 0 6} \\
(0.2145)\end{array}$ & $\begin{array}{c}-0.4879 \\
(0.2163)\end{array}$ & $\begin{array}{l}0.4917^{\star *} \\
(0.2159)\end{array}$ & $\begin{array}{c}-0.4813^{ \pm+} \\
(0.2144)\end{array}$ & $\begin{array}{l}0.4898^{\circ+} \\
(0.2157)\end{array}$ & $\begin{array}{l}-0.4931^{\prime \prime} \\
(0.2162)\end{array}$ \\
\hline 1901 & $\begin{array}{l}-0.2590 \\
(0.2008)\end{array}$ & $\begin{array}{l}-0.2659 \\
(0.2024)\end{array}$ & $\begin{array}{l}-0.2699 \\
(0.2009)\end{array}$ & $\begin{array}{l}-0.2600 \\
(0.2007)\end{array}$ & $\begin{array}{l}-0.2681 \\
(0.2020)\end{array}$ & $\begin{array}{l}-0.2717 \\
(0.2006)\end{array}$ \\
\hline 1902 & $\begin{array}{c}0.1195 \\
(0.2821)\end{array}$ & $\begin{array}{c}0.1058 \\
(0.2826)\end{array}$ & $\begin{array}{c}0.0983 \\
(0.2838)\end{array}$ & $\begin{array}{c}0.1469 \\
(0.2833)\end{array}$ & $\begin{array}{c}0.1275 \\
(0.2851)\end{array}$ & $\begin{array}{c}0.1255 \\
(0.2854)\end{array}$ \\
\hline 1903 & $\begin{array}{l}-0.0991 \\
(0.2001)\end{array}$ & $\begin{array}{l}-0.1107 \\
(0.1987)\end{array}$ & $\begin{array}{l}-0.1381 \\
(0.2048)\end{array}$ & $\begin{array}{c}-0.0703 \\
(0.1995)\end{array}$ & $\begin{array}{c}-0.0880 \\
(0.2017)\end{array}$ & $\begin{array}{c}-0.1092 \\
(0.2058)\end{array}$ \\
\hline 1904 & $\begin{array}{l}-0.2386 \\
(0.3007)\end{array}$ & $\begin{array}{c}-0.2899 \\
(0.2865)\end{array}$ & $\begin{array}{l}-0.2911 \\
(0.2919)\end{array}$ & $\begin{array}{l}-0.2096 \\
(0.3011)\end{array}$ & $\begin{array}{l}-0.2627 \\
(0.2922)\end{array}$ & $\begin{array}{l}-0.2605 \\
(0.2945)\end{array}$ \\
\hline 1905 & $\begin{array}{l}-0.2423 \\
(0.2955)\end{array}$ & $\begin{array}{l}-0.2947 \\
(0.3007)\end{array}$ & $\begin{array}{l}-0.2964 \\
(0.3046)\end{array}$ & $\begin{array}{l}-0.2065 \\
(0.2942)\end{array}$ & $\begin{array}{c}-0.2614 \\
(0.3010)\end{array}$ & $\begin{array}{l}-0.2595 \\
(0.3038)\end{array}$ \\
\hline 1906 & $\begin{array}{c}0.1772 \\
(0.3072)\end{array}$ & $\begin{array}{c}0.1253 \\
(0.3020)\end{array}$ & $\begin{array}{c}0.1228 \\
(0.3044)\end{array}$ & $\begin{array}{c}0.2132 \\
(0.3043)\end{array}$ & $\begin{array}{c}0.1589 \\
(0.3035)\end{array}$ & $\begin{array}{c}0.1599 \\
(0.3023)\end{array}$ \\
\hline 1907 & $\begin{array}{l}-0.5454 \\
(0.3550)\end{array}$ & $\begin{array}{l}-0.6326 \\
(0.3896)\end{array}$ & $\begin{array}{l}-0.6537 \\
(0.4014)\end{array}$ & $\begin{array}{l}-0.5069 \\
(0.3475)\end{array}$ & $\begin{array}{l}-0.6008 \\
(0.3848)\end{array}$ & $\begin{array}{l}-0.6121 \\
(0.3951)\end{array}$ \\
\hline 1908 & $\begin{array}{l}-0.4088 \\
(0.3671)\end{array}$ & $\begin{array}{r}-0.5233 \\
(0.4313)\end{array}$ & $\begin{array}{l}-0.6123 \\
(0.4698)\end{array}$ & $\begin{array}{l}-0.3597 \\
(0.3582)\end{array}$ & $\begin{array}{l}-0.4858 \\
(0.4265)\end{array}$ & $\begin{array}{l}-0.5679 \\
(0.4658)\end{array}$ \\
\hline 1909 & $\begin{array}{l}\mathbf{0 . 6 3 6 5} \\
(0.3692)\end{array}$ & $\begin{array}{c}\mathbf{0 . 8 0 1 6} \\
(0.3702)\end{array}$ & $\begin{array}{l}\mathbf{0 . 8 6 6 3} \\
(0.4261)\end{array}$ & $\begin{array}{l}-0.5875 \\
(0.3605)\end{array}$ & $\begin{array}{l}0.7585^{\star} \\
(0.3699)\end{array}$ & $\begin{array}{l}\mathbf{0 . 8 1 9 2} \\
(0.4263)\end{array}$ \\
\hline 1910 & $\begin{array}{l}-0.4709 \\
(0.3829)\end{array}$ & $\begin{array}{l}-0.6608 \\
(0.4376)\end{array}$ & $\begin{array}{l}-0.7394 \\
(0.5082)\end{array}$ & $\begin{array}{l}-0.4181 \\
(0.3624)\end{array}$ & $\begin{array}{l}-0.6090 \\
(0.4233)\end{array}$ & $\begin{array}{l}-0.6907 \\
(0.4982)\end{array}$ \\
\hline 1911 & $\begin{array}{l}\mathbf{0 . 8 7 2 6} \\
(0.3022)\end{array}$ & $\begin{array}{c}-1.0622^{=} \\
(0.3640)\end{array}$ & $\begin{array}{c}-1.1419 \\
(0.4083)\end{array}$ & $\begin{array}{c}\mathbf{0 . 8 2 1 1} \\
(0.3023)\end{array}$ & $\begin{array}{c}-1.0113 \\
(0.3636)\end{array}$ & $\begin{array}{c}-1.0936^{\star} \\
(0.4053)\end{array}$ \\
\hline 1912 & $\begin{array}{c}-1.3064^{*=} \\
(0.4027)\end{array}$ & $\begin{array}{c}-1.5612^{=} \\
(0.4546)\end{array}$ & $\begin{array}{c}-1.5945^{\circ} \\
(0.5160)\end{array}$ & $\begin{array}{c}-1.3522^{=} \\
(0.4136)\end{array}$ & $\begin{array}{c}-1.5909 \\
(0.4589)\end{array}$ & $\begin{array}{c}-1.6470^{\prime-} \\
(0.5264)\end{array}$ \\
\hline 1913 & $\begin{array}{c}-1.0423^{*} \\
(0.3040)\end{array}$ & $\begin{array}{c}-1.2906^{\star} \\
(0.3839)\end{array}$ & $\begin{array}{c}-1.3348^{*} \\
(0.4478)\end{array}$ & $\begin{array}{c}-1.0972= \\
(0.3175)\end{array}$ & $\begin{array}{c}-1.3273^{\star *} \\
(0.3885)\end{array}$ & $\begin{array}{c}-1.3941 \\
(0.4572)\end{array}$ \\
\hline 1914 & $\begin{array}{c}-1.6813^{\star \prime} \\
(0.5248)\end{array}$ & $\begin{array}{c}-1.9592 \\
(0.5699)\end{array}$ & $\begin{array}{c}-1.9802^{\circ} \\
(0.6430)\end{array}$ & $\begin{array}{c}-1.7786^{\star-} \\
(0.5317)\end{array}$ & $\begin{array}{c}-2.0319 \\
(0.5741)\end{array}$ & $\begin{array}{c}-2.0838 \\
(0.6512)\end{array}$ \\
\hline 1915 & $\begin{array}{c}-1.7764^{ \pm *} \\
(0.4333)\end{array}$ & $\begin{array}{c}-2.0475^{-} \\
(0.4848)\end{array}$ & $\begin{array}{l}-2.0709^{\circ} \\
(0.5489)\end{array}$ & $\begin{array}{c}-1.9002= \\
(0.4322)\end{array}$ & $\begin{array}{l}-2.1497^{\star} \\
(0.4916)\end{array}$ & $\begin{array}{c}-2.2037^{\prime} \\
(0.5599)\end{array}$ \\
\hline 1916 & $\begin{array}{c}-1.4464^{\neq} \\
(0.5242)\end{array}$ & $\begin{array}{c}-1.6952= \\
(0.5120)\end{array}$ & $\begin{array}{c}-1.7406^{\star \prime} \\
(0.5986)\end{array}$ & $\begin{array}{c}-1.5859= \\
(0.5058)\end{array}$ & $\begin{array}{c}-1.8080^{\prime \prime} \\
(0.5055)\end{array}$ & $\begin{array}{c}-1.8859 \\
(0.5942)\end{array}$ \\
\hline 1917 & $\begin{array}{c}-1.2909 \\
(0.5691)\end{array}$ & $\begin{array}{c}\mathbf{- 1 . 5 2 0 9} \\
(0.5112)\end{array}$ & $\begin{array}{c}-1.5957^{\star *} \\
(0.5640)\end{array}$ & $\begin{array}{c}-1.4350 \\
(0.5355)\end{array}$ & $\begin{array}{c}-1.6424 \\
(0.4819)\end{array}$ & $\begin{array}{c}-1.7514^{*} \\
(0.5482)\end{array}$ \\
\hline 1918 & $\begin{array}{l}-2.2023^{*} \\
(0.5476)\end{array}$ & $\begin{array}{c}-2.4095 \\
(0.5570)\end{array}$ & $\begin{array}{l}-2.5202^{*} \\
(0.6056)\end{array}$ & $\begin{array}{c}-2.3408^{=} \\
(0.5089)\end{array}$ & $\begin{array}{l}-2.5268^{\star} \\
(0.5338)\end{array}$ & $\begin{array}{c}-2.6709 \\
(0.5919)\end{array}$ \\
\hline 1919 & $\begin{array}{l}-2.4928^{\circ} \\
(0.5328)\end{array}$ & $\begin{array}{c}-2.6900^{\prime} \\
(0.5186)\end{array}$ & $\begin{array}{l}-2.8209^{\circ} \\
(0.5586)\end{array}$ & $\begin{array}{c}-2.6303^{=-} \\
(0.5659)\end{array}$ & $\begin{array}{l}-2.8079^{=} \\
(0.5463)\end{array}$ & $\begin{array}{c}-2.9702^{=} \\
(0.6106)\end{array}$ \\
\hline 1920 & $\begin{array}{c}-1.5776^{\circ} \\
(0.4705)\end{array}$ & $\begin{array}{c}-1.7509= \\
(0.5862)\end{array}$ & $\begin{array}{c}-1.9128 \\
(0.6427)\end{array}$ & $\begin{array}{c}-1.7213^{ \pm} \\
(0.5104)\end{array}$ & $\begin{array}{c}-\mathbf{1 . 8 7 0 7} \\
(0.6193)\end{array}$ & $\begin{array}{l}-2.0666^{-5} \\
(0.6913)\end{array}$ \\
\hline
\end{tabular}

Notes: Standard errors robust to clustering by state are shown in parentheses. Statistical significance at the $90 \%$ and $95 \%$ levels is indicated with * and $*$, respectively. Reference year is 1899 . State effects are omitted. 


\begin{tabular}{|c|c|c|c|c|}
\hline \multicolumn{5}{|c|}{$\begin{array}{c}\text { Table } 5 \text { - Parameter Estimates for Poisson Model } \\
\text { of Fraternal Insurer Formations }\end{array}$} \\
\hline & (7) & (8) & (9) & (10) \\
\hline Workers Comp & $\begin{array}{c}0.3045 \\
(0.3336)\end{array}$ & & & \\
\hline Armstrong & & $\begin{array}{c}0.0603 \\
(0.2026)\end{array}$ & & \\
\hline Minimum Rate & & & $\begin{array}{l}\mathbf{0 . 7 3 3 2} \\
(0.2311)\end{array}$ & \\
\hline Oversight Index & & & & $\begin{array}{c}0.1723 \\
(0.1275)\end{array}$ \\
\hline Policy Index & & & & $\begin{array}{c}0.0851 \\
(0.1181)\end{array}$ \\
\hline Conduct Index & & & & $\begin{array}{c}0.0545 \\
(0.0819)\end{array}$ \\
\hline 1900 & $\begin{array}{l}\mathbf{0 . 4 8 0 0} \\
(0.2144)\end{array}$ & $\begin{array}{l}\mathbf{0 . 4 8 0 0} \\
(0.2144)\end{array}$ & $\begin{array}{l}\mathbf{0 . 4 8 1 4} \\
(0.2144)\end{array}$ & $\begin{array}{l}\mathbf{0 . 4 9 1 6} \\
(0.2165)\end{array}$ \\
\hline 1901 & $\begin{array}{l}-0.2578 \\
(0.2006)\end{array}$ & $\begin{array}{l}-0.2578 \\
(0.2006)\end{array}$ & $\begin{array}{l}-0.2603 \\
(0.2006)\end{array}$ & $\begin{array}{l}-0.2692 \\
(0.2004)\end{array}$ \\
\hline 1902 & $\begin{array}{l}0.0684 \\
(0.2807)\end{array}$ & $\begin{array}{c}0.0683 \\
(0.2808)\end{array}$ & $\begin{array}{c}0.1496 \\
(0.2856)\end{array}$ & $\begin{array}{c}0.0512 \\
(0.2840)\end{array}$ \\
\hline 1903 & $\begin{array}{l}-0.1559 \\
(0.2023)\end{array}$ & $\begin{array}{l}-0.1561 \\
(0.2023)\end{array}$ & $\begin{array}{l}-0.0743 \\
(0.2017)\end{array}$ & $\begin{array}{l}-0.1895 \\
(0.2069)\end{array}$ \\
\hline 1904 & $\begin{array}{l}-0.2958 \\
(0.3073)\end{array}$ & $\begin{array}{l}-0.2960 \\
(0.3074)\end{array}$ & $\begin{array}{l}-0.2136 \\
(0.3033)\end{array}$ & $\begin{array}{l}-0.3489 \\
(0.2958)\end{array}$ \\
\hline 1905 & $\begin{array}{l}-0.3143 \\
(0.3045)\end{array}$ & $\begin{array}{l}-0.3145 \\
(0.3047)\end{array}$ & $\begin{array}{l}-0.2074 \\
(0.2985)\end{array}$ & $\begin{array}{l}-0.3695 \\
(0.3073)\end{array}$ \\
\hline 1906 & $\begin{array}{l}0.1048 \\
(0.3170)\end{array}$ & $\begin{array}{c}0.1046 \\
(0.3172)\end{array}$ & $\begin{array}{c}0.2122 \\
(0.3077)\end{array}$ & $\begin{array}{c}0.0468 \\
(0.3094)\end{array}$ \\
\hline 1907 & $\begin{array}{l}\mathbf{0 . 6 2 9 4 ^ { * }} \\
(0.3579)\end{array}$ & $\begin{array}{l}\mathbf{0 . 6 3 4 3 ^ { * }} \\
(0.3559)\end{array}$ & $\begin{array}{l}-0.5195 \\
(0.3499)\end{array}$ & 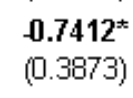 \\
\hline 1908 & $\begin{array}{l}-0.5285 \\
(0.3441)\end{array}$ & $\begin{array}{l}-0.5554 \\
(0.3587)\end{array}$ & $\begin{array}{c}-0.3909 \\
(0.3470)\end{array}$ & $\begin{array}{l}\mathbf{0 . 7 9 4 3 ^ { * }} \\
(0.4320)\end{array}$ \\
\hline 1909 & $\begin{array}{l}0.7574= \\
(0.3372)\end{array}$ & $\begin{array}{l}-0.7861 \\
(0.3740)\end{array}$ & $\begin{array}{l}\mathbf{0 . 6 1 9 7 ^ { \star }} \\
(0.3272)\end{array}$ & $\begin{array}{c}-1.0453 \\
(0.4117)\end{array}$ \\
\hline 1910 & $\begin{array}{l}\mathbf{0 . 6 0 6 5 ^ { * }} \\
(0.3276)\end{array}$ & $\begin{array}{l}\mathbf{0 . 6 4 1 0 ^ { * }} \\
(0.3677)\end{array}$ & $\begin{array}{l}-0.4615 \\
(0.3197)\end{array}$ & $\begin{array}{l}\mathbf{0 . 9 4 9 8} \\
(0.4719)\end{array}$ \\
\hline 1911 & $\begin{array}{c}-1.0084 \\
(0.2945)\end{array}$ & $\begin{array}{c}-1.0310 \\
(0.3162)\end{array}$ & $\begin{array}{c}\mathbf{0 . 8 5 1 4} \\
(0.2936)\end{array}$ & $\begin{array}{c}-1.3406 \\
(0.3802)\end{array}$ \\
\hline 1912 & $\begin{array}{c}-1.5691^{* *} \\
(0.4536)\end{array}$ & $\begin{array}{c}-1.5173 \\
(0.4244)\end{array}$ & $\begin{array}{c}-1.2246^{*} \\
(0.3588)\end{array}$ & $\begin{array}{r}-1.9269^{*} \\
(0.4960)\end{array}$ \\
\hline 1913 & $\begin{array}{c}-1.3285^{*} \\
(0.3877)\end{array}$ & $\begin{array}{c}-1.2543^{*} \\
(0.3363)\end{array}$ & $\begin{array}{c}\mathbf{0 . 9 4 7 9} \\
(0.2751)\end{array}$ & $\begin{array}{r}-1.6664 \\
(0.4389)\end{array}$ \\
\hline 1914 & $\begin{array}{c}-2.0891= \\
(0.6078)\end{array}$ & $\begin{array}{l}-1.9977^{*} \\
(0.5123)\end{array}$ & $\begin{array}{c}-1.6082= \\
(0.4721)\end{array}$ & $\begin{array}{l}-2.4166 \\
(0.5800)\end{array}$ \\
\hline 1915 & $\begin{array}{l}-2.2592= \\
(0.5218)\end{array}$ & $\begin{array}{l}-2.1654^{=} \\
(0.4230)\end{array}$ & $\begin{array}{c}-1.7148 \\
(0.4083)\end{array}$ & $\begin{array}{l}-2.5844 \\
(0.5166)\end{array}$ \\
\hline 1916 & $\begin{array}{c}-1.9364= \\
(0.5601)\end{array}$ & $\begin{array}{c}-1.7733^{*} \\
(0.4496)\end{array}$ & $\begin{array}{c}-1.3190 \\
(0.4328)\end{array}$ & $\begin{array}{l}-2.1929 \\
(0.5158)\end{array}$ \\
\hline 1917 & $\begin{array}{c}-1.8449^{*} \\
(0.5672)\end{array}$ & $\begin{array}{l}-1.6850 \\
(0.5094)\end{array}$ & $\begin{array}{c}-1.1985= \\
(0.5171)\end{array}$ & $\begin{array}{l}-2.1062 \\
(0.5304)\end{array}$ \\
\hline 1918 & $\begin{array}{c}-2.7807^{*} \\
(0.5118)\end{array}$ & $\begin{array}{l}-2.6151= \\
(0.4311)\end{array}$ & $\begin{array}{l}-2.1288= \\
(0.4240)\end{array}$ & $\begin{array}{l}3.0419 \\
(0.4666)\end{array}$ \\
\hline 1919 & $\begin{array}{l}-\mathbf{3 . 0 9 9 3}^{*} \\
(0.5916)\end{array}$ & $\begin{array}{l}-2.9165^{ \pm} \\
(0.5135)\end{array}$ & $\begin{array}{l}-2.4304= \\
(0.4276)\end{array}$ & $\begin{array}{l}3.3434 \\
(0.5483)\end{array}$ \\
\hline 1920 & $\begin{array}{l}-2.2266 \\
(0.5684)\end{array}$ & $\begin{array}{l}-2.0152= \\
(0.3931)\end{array}$ & $\begin{array}{c}-1.5210= \\
(0.3154)\end{array}$ & $\begin{array}{l}2.4410= \\
(0.5046)\end{array}$ \\
\hline
\end{tabular}




\begin{tabular}{|lr||cc|}
\hline \multicolumn{4}{|c|}{$\begin{array}{c}\text { Table 6 - Sample Means } \\
\text { (Logistic Regressions) }\end{array}$} \\
\hline \hline Fraternal Law Variables & Year Dummies \\
Force Bill & 0.137 & & \\
Mobile Bill & 0.056 & $\mathbf{1 8 9 9}$ & 0.065 \\
Minimum Rate & 0.194 & $\mathbf{1 9 0 0}$ & 0.041 \\
& & $\mathbf{1 9 0 1}$ & 0.051 \\
Other Law Variables & & $\mathbf{1 9 0 2}$ & 0.071 \\
& & $\mathbf{1 9 0 3}$ & 0.063 \\
Armstrong & 0.250 & $\mathbf{1 9 0 4}$ & 0.056 \\
Basic Oversight & 0.837 & $\mathbf{1 9 0 5}$ & 0.065 \\
Valuation Deposit & 0.129 & $\mathbf{1 9 0 6}$ & 0.105 \\
Voucher & 0.164 & $\mathbf{1 9 0 7}$ & 0.062 \\
Basic Conduct & 0.086 & $\mathbf{1 9 0 8}$ & 0.060 \\
Other Expense & 0.029 & $\mathbf{1 9 0 9}$ & 0.066 \\
Compensation & 0.173 & $\mathbf{1 9 1 0}$ & 0.060 \\
Board & 0.232 & $\mathbf{1 9 1 1}$ & 0.041 \\
Political & 0.057 & $\mathbf{1 9 1 2}$ & 0.026 \\
Basic Policy & 0.189 & $\mathbf{1 9 1 3}$ & 0.031 \\
Minimum Capital & 55.994 & $\mathbf{1 9 1 4}$ & 0.021 \\
Workers' Comp & 0.122 & $\mathbf{1 9 1 5}$ & 0.014 \\
& & $\mathbf{1 9 1 6}$ & 0.022 \\
Conduct Index & 1.948 & $\mathbf{1 9 1 7}$ & 0.025 \\
Oversight Index & 3.068 & $\mathbf{1 9 1 8}$ & 0.010 \\
Policy Index & 1.635 & $\mathbf{1 9 1 9}$ & 0.021 \\
Total Index & 6.651 & $\mathbf{1 9 2 0}$ & 0.023 \\
\hline Observations: 1259 & $\mathbf{9 2 6}$ fratneral, 333 legal reserve) \\
\hline \multicolumn{2}{|c|}{} & & \\
\hline
\end{tabular}


Table 7 (Part 1) - Parameter Estimates and Implied Probabilities of Fraternal Formation for Logit Model of Choice Between Fraternal and Legal Reserve Forms

\section{(1)}

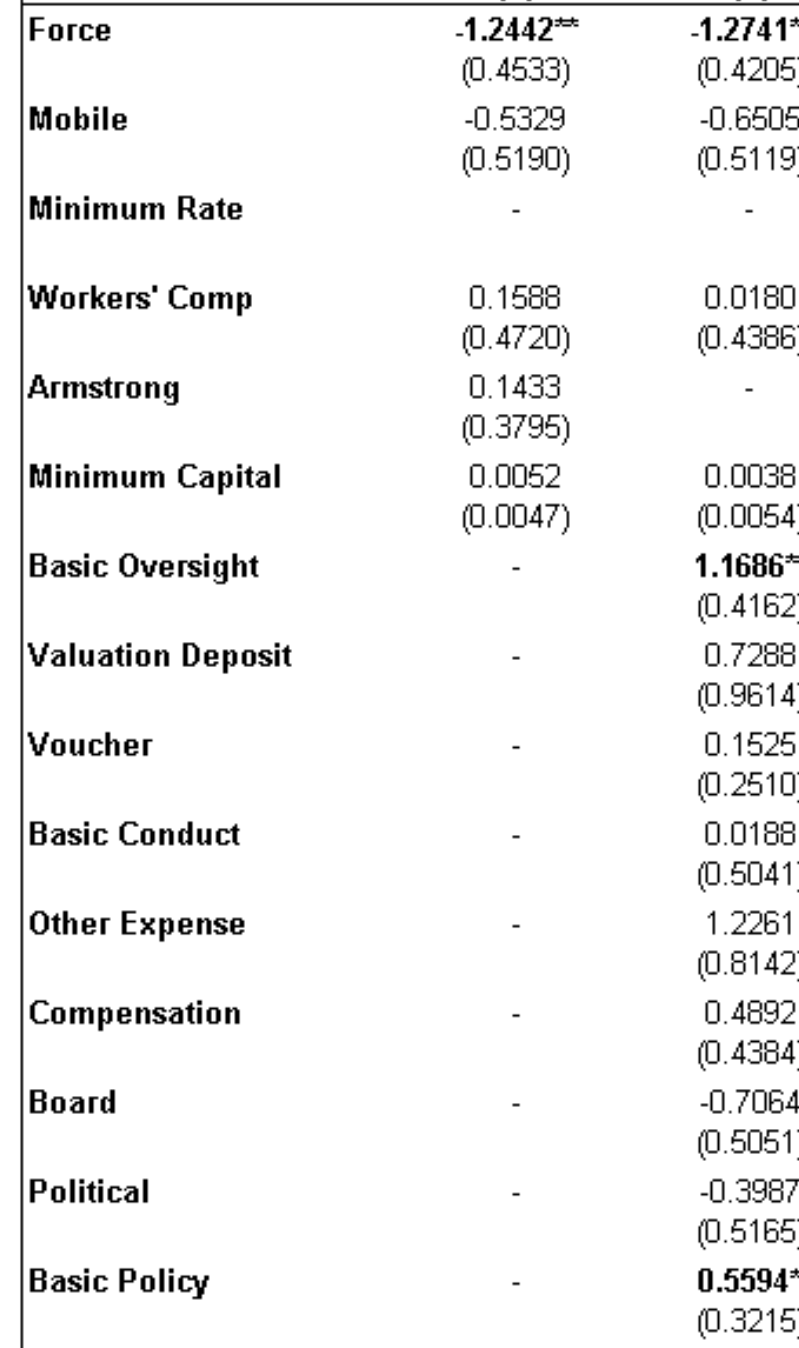

(3)

$-1.2481$

(0.4547)

$-0.5628$

(0.5161)

Oversight Index

.
(4)

(5) (6)

$\begin{array}{cccc}- & \mathbf{- 0 . 8 2 0 7 *} & \mathbf{- 0 . 9 0 7 2} & \mathbf{0 . 8 4 0 2} \\ & (0.3714) & (0.3681) & (0.3706) \\ 0.0894 & 0.1119 & -0.0186 & 0.0500 \\ (0.4795) & (0.4934) & (0.4522) & (0.5077) \\ - & 0.1768 & - & - \\ & (0.3738) & & \\ 0.0032 & 0.0047 & 0.0038 & 0.0026 \\ (0.0052) & (0.0044) & (0.0052) & (0.0049)\end{array}$

$12120^{\prime}$

(0.4330)

0.6609

(0.9480)

0.0723

(0.3040)

0.0378

(0.4931)

1.2087

(0.8942)

0.3758

(0.4486)

$-0.7091$

(0.4992)

$-0.3795$

(0.5147)

0.6935

(0.3417)

0.5221

(0.1805)

0.5222

(0.1749)

$0.2309=$

(0.1168)

$0.2348=$

$-0.1288$

(0.1168)

(0.1202)

$-0.1258$

(0.1174)

\section{Implied Probability of Fraternal Formation}

\begin{tabular}{|c|c|c|c|c|c|c|}
\hline At Sample Means & $83 \%$ & $81 \%$ & $80 \%$ & $80 \%$ & $81 \%$ & $81 \%$ \\
\hline With Force Bill & $59 \%$ & $54 \%$ & $54 \%$ & - & - & - \\
\hline With Mobile Bill & $74 \%$ & $68 \%$ & $70 \%$ & - & - & - \\
\hline With Minimum Rate Law & - & - & - & $64 \%$ & $63 \%$ & $64 \%$ \\
\hline
\end{tabular}




\begin{tabular}{|c|c|c|c|c|c|c|}
\hline \multicolumn{6}{|c|}{$\begin{array}{l}\text { Table } 7 \text { (Part 2) - Parameter Estimates for Year Effects } \\
\text { for Logit Model of Choice Between Fraternal and Legal Reserve Forms }\end{array}$} & \multirow[b]{2}{*}{ (6) } \\
\hline & (1) & (2) & (3) & (4) & (5) & \\
\hline 1900 & $\begin{array}{l}-0.0629 \\
(0.8048)\end{array}$ & $\begin{array}{l}-0.2407 \\
(0.8193)\end{array}$ & $\begin{array}{l}-0.1342 \\
(0.7875)\end{array}$ & $\begin{array}{l}-0.0546 \\
(0.7991)\end{array}$ & $\begin{array}{l}-0.2473 \\
(0.8220)\end{array}$ & $\begin{array}{l}-0.1324 \\
(0.7837)\end{array}$ \\
\hline 1901 & $\begin{array}{c}0.1930 \\
(0.6104)\end{array}$ & $\begin{array}{c}0.1099 \\
(0.6023)\end{array}$ & $\begin{array}{c}0.1004 \\
(0.6017)\end{array}$ & $\begin{array}{c}0.1748 \\
(0.6111)\end{array}$ & $\begin{array}{c}0.0886 \\
(0.6029)\end{array}$ & $\begin{array}{c}0.0790 \\
(0.6019)\end{array}$ \\
\hline 1902 & $\begin{array}{c}0.0697 \\
(0.6341)\end{array}$ & $\begin{array}{c}0.0291 \\
(0.6308)\end{array}$ & $\begin{array}{c}0.0767 \\
(0.6216)\end{array}$ & $\begin{array}{c}0.0344 \\
(0.6300)\end{array}$ & $\begin{array}{l}-0.0145 \\
(0.6332)\end{array}$ & $\begin{array}{c}0.0314 \\
(0.6166)\end{array}$ \\
\hline 1903 & $\begin{array}{l}-0.4363 \\
(0.6235)\end{array}$ & $\begin{array}{l}-0.4942 \\
(0.5955)\end{array}$ & $\begin{array}{l}-0.5006 \\
(0.6197)\end{array}$ & $\begin{array}{l}-0.4773 \\
(0.6393)\end{array}$ & $\begin{array}{l}-0.5418 \\
(0.6102)\end{array}$ & $\begin{array}{l}-0.5493 \\
(0.6403)\end{array}$ \\
\hline 1904 & $\begin{array}{l}-0.6332 \\
(0.6098)\end{array}$ & $\begin{array}{l}-0.8001 \\
(0.6407)\end{array}$ & $\begin{array}{l}-0.7177 \\
(0.6137)\end{array}$ & $\begin{array}{l}-0.7172 \\
(0.6004)\end{array}$ & $\begin{array}{l}-0.8826 \\
(0.6286)\end{array}$ & $\begin{array}{l}-0.8104 \\
(0.6088)\end{array}$ \\
\hline 1905 & $\begin{array}{c}-1.4100 \\
(0.4956)\end{array}$ & $\begin{array}{c}-1.5082^{*} \\
(0.5280)\end{array}$ & $\begin{array}{c}-1.4473^{*} \\
(0.4991)\end{array}$ & $\begin{array}{c}-1.5000^{*} \\
(0.5171)\end{array}$ & $\begin{array}{c}-1.5965^{\circ} \\
(0.5525)\end{array}$ & $\begin{array}{c}-1.5488 \\
(0.5291)\end{array}$ \\
\hline 1906 & $\begin{array}{l}-1.5257^{ \pm+} \\
(0.3923)\end{array}$ & $\begin{array}{c}-1.6408^{*} \\
(0.4422)\end{array}$ & $\begin{array}{l}-1.5978= \\
(0.3968)\end{array}$ & $\begin{array}{c}-1.6129= \\
(0.4025)\end{array}$ & $\begin{array}{c}-1.7251 \\
(0.4538)\end{array}$ & $\begin{array}{c}-1.6916 \\
(0.4143)\end{array}$ \\
\hline 1907 & $\begin{array}{l}-2.3809^{ \pm *} \\
(0.4958)\end{array}$ & $\begin{array}{l}-2.6178^{*} \\
(0.5486)\end{array}$ & $\begin{array}{l}-2.5951 * \\
(0.5152)\end{array}$ & $\begin{array}{l}-2.4631= \\
(0.5074)\end{array}$ & $\begin{array}{l}-2.6920= \\
(0.5602)\end{array}$ & $\begin{array}{l}-2.6834= \\
(0.5363)\end{array}$ \\
\hline 1908 & $\begin{array}{l}-2.0370^{=-} \\
(0.5858)\end{array}$ & $\begin{array}{l}-2.1690 \\
(0.5813)\end{array}$ & $\begin{array}{l}-2.3652^{*} \\
(0.5680)\end{array}$ & $\begin{array}{l}-2.1448^{= \pm} \\
(0.5968)\end{array}$ & $\begin{array}{l}-2.2588= \\
(0.5937)\end{array}$ & $\begin{array}{l}-2.4719= \\
(0.5911)\end{array}$ \\
\hline 1909 & $\begin{array}{l}-2.7352= \\
(0.5543)\end{array}$ & $\begin{array}{l}-2.9853= \\
(0.5385)\end{array}$ & $\begin{array}{l}3.1293^{*} \\
(0.4978)\end{array}$ & $\begin{array}{l}-2.8287^{*} \\
(0.5535)\end{array}$ & $\begin{array}{l}-3.0649= \\
(0.5440)\end{array}$ & $\begin{array}{l}-3.2229= \\
(0.5129)\end{array}$ \\
\hline 1910 & $\begin{array}{l}-2.0622= \\
(0.5316)\end{array}$ & $\begin{array}{l}-2.3693 \\
(0.5392)\end{array}$ & $\begin{array}{l}-2.5457^{*} \\
(0.5181)\end{array}$ & $\begin{array}{l}-2.1813= \\
(0.5223)\end{array}$ & $\begin{array}{l}-2.4820= \\
(0.5366)\end{array}$ & $\begin{array}{l}-2.6646^{=} \\
(0.5221)\end{array}$ \\
\hline 1911 & $\begin{array}{l}-\mathbf{1 . 8 2 8 8}= \\
(0.6929)\end{array}$ & $\begin{array}{l}-2.0753= \\
(0.6597)\end{array}$ & $\begin{array}{l}-2.2921= \\
(0.6458)\end{array}$ & $\begin{array}{l}-1.9587^{*} \\
(0.6868)\end{array}$ & $\begin{array}{l}-2.1921= \\
(0.6574)\end{array}$ & $\begin{array}{l}-2.4219= \\
(0.6494)\end{array}$ \\
\hline 1912 & $\begin{array}{l}-2.0332^{-=} \\
(0.6848)\end{array}$ & $\begin{array}{l}-2.3025 \\
(0.6269)\end{array}$ & $\begin{array}{l}-2.5572^{+-} \\
(0.6239)\end{array}$ & $\begin{array}{l}-2.0502^{+-} \\
(0.6762)\end{array}$ & $\begin{array}{l}-2.3280^{*-} \\
(0.6273)\end{array}$ & $\begin{array}{l}-2.5760^{+0} \\
(0.6237)\end{array}$ \\
\hline 1913 & $\begin{array}{l}-1.1640 \\
(0.7601)\end{array}$ & $\begin{array}{l}-1.3090^{\star} \\
(0.7908)\end{array}$ & $\begin{array}{l}-1.5663^{\star} \\
(0.8155)\end{array}$ & $\begin{array}{l}-1.1356 \\
(0.7646)\end{array}$ & $\begin{array}{l}-1.2866 \\
(0.7957)\end{array}$ & $\begin{array}{l}-1.5455^{*} \\
(0.8253)\end{array}$ \\
\hline 1914 & $\begin{array}{l}-2.7083^{=} \\
(0.8276)\end{array}$ & $\begin{array}{l}-2.9362= \\
(0.8781)\end{array}$ & $\begin{array}{l}3.2304= \\
(0.8726)\end{array}$ & $\begin{array}{l}-2.6433= \\
(0.8272)\end{array}$ & $\begin{array}{l}-2.8805^{=} \\
(0.8810)\end{array}$ & $\begin{array}{l}-3.1737^{\circ} \\
(0.8817)\end{array}$ \\
\hline 1915 & $\begin{array}{l}-2.0835= \\
(0.8255)\end{array}$ & $\begin{array}{l}-2.3717^{*} \\
(0.7490)\end{array}$ & $\begin{array}{l}-2.6128= \\
(0.7744)\end{array}$ & $\begin{array}{l}-2.0534^{=*} \\
(0.8445)\end{array}$ & $\begin{array}{l}-2.3286^{* *} \\
(0.7706)\end{array}$ & $\begin{array}{l}-2.5894 \\
(0.7930)\end{array}$ \\
\hline 1916 & $\begin{array}{l}-2.2425^{ \pm-} \\
(0.7496)\end{array}$ & $\begin{array}{l}-2.4804^{\prime+} \\
(0.7752)\end{array}$ & $\begin{array}{l}-2.7887^{ \pm *} \\
(0.8208)\end{array}$ & $\begin{array}{l}-2.1360^{ \pm t} \\
(0.7638)\end{array}$ & $\begin{array}{l}-2.3717^{\prime \prime} \\
(0.7776)\end{array}$ & $\begin{array}{l}-2.6916^{=} \\
(0.8389)\end{array}$ \\
\hline 1917 & $\begin{array}{l}-1.9427^{ \pm+} \\
(0.8823)\end{array}$ & $\begin{array}{l}-2.1999= \\
(0.8657)\end{array}$ & $\begin{array}{l}-2.5257^{*+} \\
(0.9101)\end{array}$ & $\begin{array}{l}-1.9318= \\
(0.9033)\end{array}$ & $\begin{array}{l}-2.1708 \\
(0.8822)\end{array}$ & $\begin{array}{l}-2.5262^{= \pm} \\
(0.9406)\end{array}$ \\
\hline 1918 & $\begin{array}{l}-2.1914= \\
(0.9830)\end{array}$ & $\begin{array}{l}-2.3940 \\
(0.9884)\end{array}$ & $\begin{array}{l}-2.6843^{* *} \\
(1.0334)\end{array}$ & $\begin{array}{l}-2.0959^{* *} \\
(1.0022)\end{array}$ & $\begin{array}{l}2.3046^{* *} \\
(0.9983)\end{array}$ & $\begin{array}{l}-2.6083= \\
(1.0549)\end{array}$ \\
\hline 1919 & $\begin{array}{l}\mathbf{3 . 4 2 8 7} \\
(0.8935)\end{array}$ & $\begin{array}{l}\mathbf{3 . 7 5 1 9} \\
(0.9367)\end{array}$ & $\begin{array}{l}4.0603= \\
(0.9953)\end{array}$ & $\begin{array}{l}\mathbf{3 . 3 9 4 6} \\
(0.9142)\end{array}$ & $\begin{array}{c}-3.7097^{*} \\
(0.9460)\end{array}$ & $\begin{array}{c}4.0282^{=-} \\
(1.0106)\end{array}$ \\
\hline 1920 & $\begin{array}{l}-2.1368= \\
(0.7884)\end{array}$ & $\begin{array}{l}-2.3146^{*} \\
(0.7718)\end{array}$ & $\begin{array}{l}-2.6832 \\
(0.8341)\end{array}$ & $\begin{array}{l}-2.0785^{-*} \\
(0.7959)\end{array}$ & $\begin{array}{l}-2.2361:= \\
(0.7603)\end{array}$ & $\begin{array}{l}-2.6300^{\prime-} \\
(0.8355)\end{array}$ \\
\hline
\end{tabular}




\begin{tabular}{|c|c|c|c|c|}
\hline \multicolumn{5}{|c|}{$\begin{array}{c}\text { Table } 8 \text { - Parameter Estimates for Logit Model of Choice } \\
\text { Between Fraternal and Legal Reserve Forms }\end{array}$} \\
\hline & (1) & (2) & (3) & (4) \\
\hline Workers Comp & $\begin{array}{l}0.2128 \\
(0.4396)\end{array}$ & & & \\
\hline Armstrong & & $\begin{array}{c}0.3398 \\
(0.3567)\end{array}$ & & \\
\hline Minimum Rate & & & $\begin{array}{l}\mathbf{0 . 8 9 2 8} \\
(0.3850)\end{array}$ & \\
\hline Oversight Index & & & & $\begin{array}{l}0.4709= \\
(0.1864)\end{array}$ \\
\hline Policy Index & & & & $\begin{array}{l}0.2752^{*-1} \\
(0.1188)\end{array}$ \\
\hline Conduct Index & & & & $\begin{array}{l}-0.0605 \\
(0.1152)\end{array}$ \\
\hline 1900 & $\begin{array}{l}-0.1064 \\
(0.8142)\end{array}$ & $\begin{array}{l}-0.1149 \\
(0.8108)\end{array}$ & $\begin{array}{l}-0.0604 \\
(0.8038)\end{array}$ & $\begin{array}{l}-0.1845 \\
(0.7968)\end{array}$ \\
\hline 1901 & $\begin{array}{l}0.1270 \\
(0.6238)\end{array}$ & $\begin{array}{l}0.1079 \\
(0.6164)\end{array}$ & $\begin{array}{l}0.1776 \\
(0.6248)\end{array}$ & $\begin{array}{l}0.0250 \\
(0.6051)\end{array}$ \\
\hline 1902 & $\begin{array}{l}-0.0667 \\
(0.6350)\end{array}$ & $\begin{array}{l}-0.0847 \\
(0.6278)\end{array}$ & $\begin{array}{l}0.0426 \\
(0.6439)\end{array}$ & $\begin{array}{l}-0.1062 \\
(0.6101)\end{array}$ \\
\hline 1903 & $\begin{array}{l}-0.6131 \\
(0.6374)\end{array}$ & $\begin{array}{l}-0.6270 \\
(0.6269)\end{array}$ & $\begin{array}{l}-0.4896 \\
(0.6553)\end{array}$ & $\begin{array}{l}-0.6949 \\
(0.6199)\end{array}$ \\
\hline 1904 & $\begin{array}{l}-0.9306 \\
(0.5930)\end{array}$ & $\begin{array}{l}-0.9267 \\
(0.5854)\end{array}$ & $\begin{array}{l}-0.7397 \\
(0.5907)\end{array}$ & $\begin{array}{l}-\mathbf{1 . 0 1 2 3}^{*} \\
(0.5915)\end{array}$ \\
\hline 1905 & $\begin{array}{c}-1.7069^{*} \\
(0.5140)\end{array}$ & $\begin{array}{c}-1.7110= \\
(0.5102)\end{array}$ & $\begin{array}{c}-1.5018= \\
(0.5330)\end{array}$ & $\begin{array}{c}-1.7775 \\
(0.5073)\end{array}$ \\
\hline 1906 & $\begin{array}{c}-1.8063^{*} \\
(0.4419)\end{array}$ & $\begin{array}{l}-1.8306^{ \pm t} \\
(0.4333)\end{array}$ & $\begin{array}{c}-1.6118 \\
(0.4239)\end{array}$ & $\begin{array}{c}-1.9310^{\circ} \\
(0.4325)\end{array}$ \\
\hline 1907 & $\begin{array}{l}-2.7165^{*} \\
(0.5230)\end{array}$ & $\begin{array}{l}-2.7279 \\
(0.5168)\end{array}$ & $\begin{array}{l}-2.4989= \\
(0.5153)\end{array}$ & $\begin{array}{l}-2.9254 \\
(0.5472)\end{array}$ \\
\hline 1908 & $\begin{array}{l}-2.3282= \\
(0.5358)\end{array}$ & $\begin{array}{l}-2.4928 \\
(0.5742)\end{array}$ & $\begin{array}{l}-2.0791= \\
(0.5535)\end{array}$ & $\begin{array}{l}-2.8375 \\
(0.5532)\end{array}$ \\
\hline 1909 & $\begin{array}{l}-2.9803^{*} \\
(0.5212)\end{array}$ & $\begin{array}{l}\text { 3.1512 } \\
(0.5799)\end{array}$ & $\begin{array}{l}-2.7523= \\
(0.4921)\end{array}$ & $\begin{array}{l}-3.5660^{\circ} \\
(0.5316)\end{array}$ \\
\hline 1910 & $\begin{array}{l}2.3436 * \\
(0.4455)\end{array}$ & $\begin{array}{l}-2.5364= \\
(0.5072)\end{array}$ & $\begin{array}{l}2.1043= \\
(0.4421)\end{array}$ & $\begin{array}{l}-3.0461 \\
(0.4947)\end{array}$ \\
\hline 1911 & $\begin{array}{l}-2.0775^{*} \\
(0.5976)\end{array}$ & $\begin{array}{l}-2.2846^{*} \\
(0.6805)\end{array}$ & $\begin{array}{c}-1.8275 \\
(0.5997)\end{array}$ & $\begin{array}{l}-2.7817 \\
(0.6246)\end{array}$ \\
\hline 1912 & $\begin{array}{l}-2.3633^{*} \\
(0.6366)\end{array}$ & $\begin{array}{l}-2.5289= \\
(0.6426)\end{array}$ & $\begin{array}{c}-1.8548= \\
(0.5876)\end{array}$ & $\begin{array}{l}3.1364 \\
(0.6033)\end{array}$ \\
\hline 1913 & $\begin{array}{c}-1.5157^{* *} \\
(0.6767)\end{array}$ & $\begin{array}{l}-1.6131 * t \\
(0.6960)\end{array}$ & $\begin{array}{l}-0.9617 \\
(0.6751)\end{array}$ & $\begin{array}{l}-2.1060^{\circ} \\
(0.7681)\end{array}$ \\
\hline 1914 & $\begin{array}{c}3.0523^{*} \\
(0.8085)\end{array}$ & $\begin{array}{l}3.2163^{=0} \\
(0.7356)\end{array}$ & $\begin{array}{l}-2.3799= \\
(0.6978)\end{array}$ & $\begin{array}{l}3.8554 \\
(0.7956)\end{array}$ \\
\hline 1915 & $\begin{array}{l}-2.3145^{*} \\
(0.7906)\end{array}$ & $\begin{array}{l}-2.4422^{* *} \\
(0.7499)\end{array}$ & $\begin{array}{c}-\mathbf{1 . 8 3 6 1} \\
(0.7553)\end{array}$ & $\begin{array}{l}\mathbf{3 . 0 8 1 8}^{+0} \\
(0.6729)\end{array}$ \\
\hline 1916 & $\begin{array}{l}-2.6289= \\
(0.6494)\end{array}$ & $\begin{array}{l}-2.7174= \\
(0.5926)\end{array}$ & $\begin{array}{l}-1.9263= \\
(0.5784)\end{array}$ & $\begin{array}{l}3.3674 \\
(0.6679)\end{array}$ \\
\hline 1917 & $\begin{array}{l}-2.5891^{*} \\
(0.8513)\end{array}$ & $\begin{array}{l}-2.6308= \\
(0.7352)\end{array}$ & $\begin{array}{c}-1.7649= \\
(0.6476)\end{array}$ & $\begin{array}{l}3.3001 \\
(0.7713)\end{array}$ \\
\hline 1918 & $\begin{array}{l}-2.6927^{*} \\
(0.8247)\end{array}$ & $\begin{array}{l}-2.7828= \\
(0.7991)\end{array}$ & $\begin{array}{l}-1.9702= \\
(0.7266)\end{array}$ & $\begin{array}{l}3.3787 \\
(0.8066)\end{array}$ \\
\hline 1919 & $\begin{array}{l}4.0125^{*} \\
(0.8455)\end{array}$ & $\begin{array}{l}4.0878= \\
(0.7818)\end{array}$ & $\begin{array}{l}3.2547^{\prime *} \\
(0.6081)\end{array}$ & $\begin{array}{l}4.7525 \\
(0.8905)\end{array}$ \\
\hline 1920 & $\begin{array}{l}-2.7413 \\
(0.7274)\end{array}$ & $\begin{array}{l}-2.8040= \\
(0.6869)\end{array}$ & $\begin{array}{c}-1.9380= \\
(0.6669)\end{array}$ & $\begin{array}{l}-3.4069 \\
(0.7321)\end{array}$ \\
\hline
\end{tabular}

